\title{
DEVELOPMENTAL NEURAL KINSHIP GROUPS IN THE LEECH ${ }^{1}$
}

\author{
ANDREW P. KRAMER AND DAVID A. WEISBLAT ${ }^{2}$ \\ Department of Molecular Biology, University of California, Berkeley, California 94720
}

Received April 2, 1984; Revised July 18, 1984; Accepted July 19, 1984

\begin{abstract}
We have traced the developmental origins of various CNS neurons and glial cells of a leech to 10 clonally related groups of cells, the bilaterally paired $\mathrm{M}, \mathrm{N}, \mathrm{O}, \mathrm{P}$, and Q kinship groups. Each kinship group is descended from one of 10 identifiable blastomeres of the early embryo, the teloblasts. Of the approximately 200 neurons in each side of a segmental ganglion, 130 to 160 are in the ipsilateral N, 20 to 50 in the 0,8 to 12 in the P, 6 to 9 in the Q, and 3 to 6 in the M kinship group. A given identified neuron or glial cell was invariably found to belong to a particular kinship group, indicating that in leech development neuronal lineage is highly stereotyped. But cells of related function and morphology do not necessarily belong to the same neuronal kinship group: of the mechanosensory neurons, the $T$ and $N$ neurons belong to the $N$, the $P_{v}$ neuron belongs to the $P$ and the $\mathbf{P}_{\mathrm{D}}$ neuron belongs to the $\mathrm{O}$ kinship group. Similarly, glial cells arise from all four ectodermal teloblasts. Conversely, neurons within a kinship group are not obviously related in structure or function: the $\mathrm{N}$ kinship group includes sensory, motor, and effector neurons and interneurons: the $\mathrm{O}$ and $\mathrm{P}$ kinship groups each include sensory neurons and interneurons; both the $\mathrm{P}$ and $\mathrm{Q}$ groups contain representatives of three distinct morphological classes of interneurons. Consequently, in early development, the determinants of neuronal identity in the leech CNS are not segregated in any obvious thematic way in the cleavages that give rise to the five bilateral pairs of teloblasts. Rather, the neural kinship groups may be merely the cvolutionary vestige of a primordial distributed nervous system, each quadrant of which was derived from one teloblast.
\end{abstract}

The role of cell lineage in neurogenesis has been studied in the development of both vertebrate and invertebrate nervous systems. One possible role is that neurons related by lineage have related functions or structures. In the work reported here, we have tested this notion. For this purpose we used glossiphoniid leeches, which are especially favorable for such studies because they arise from large, accessible embryos that undergo highly stereotyped early development (Whitman, 1878, 1887, 1892; Weisblat et al., 1980a). Moreover, simple and accurate cell lineage tracing and cell ablation techniques have been developed for these embryos (Weisblat et al., 1978, 1980b; Blair, 1982, 1983).

In the embryogenesis of glossiphoniid leeches, all segmental tissues, including the segmental nervous system, arise from the D macromere of the eight-cell embryo, via the intermediate formation of four bilateral pairs of ectodermal precursors, the $\mathrm{N}$ and $\mathrm{Q}$ teloblasts, and two sister $\mathrm{O} / \mathrm{P}$ teloblasts, plus one bilateral pair of mesodermal precursors, the $M$ teloblasts. Over the course of many hours, each teloblast generates a longitudinally oriented column of small blast cells, called the $m, n, o$, $p$, and $q$ bandlets, which contribute progeny to the ipsilateral half of the ventral nerve cord. (The two O/P teloblasts on each

\footnotetext{
${ }^{1}$ This research was supported by National Institutes of Health Grants HD 17088 and NS 12818, March of Dimes Birth Defects Foundation Grant 1-738, and National Science Foundation Grant BNS79-12400. We thank Gunther S. Stent for many stimulating discussions.

${ }^{2}$ To whom correspondence should be sent, at his present address: Department of Zoology, University of California, Berkeley, CA 94720.
}

side generate equivalent bandlets, to which distinct $\mathrm{O}$ and $\mathrm{P}$ identities and fates are assigned on the basis of their relative position in the embryo; any given $\mathrm{O} / \mathrm{P}$ teloblast may be referred to as a generative $\mathrm{O}$ or generative $\mathrm{P}$ teloblast once the fate of its progeny is known (Weisblat and Blair, 1984; M. Shankland and D. A. Weisblat, manuscript in preparation).) The cells of each half (left or right) of each segmental ganglion may therefore be divided into distinct kinship groups according to their teloblast of origin. Members of each kinship group can be identified by injecting a cell lineage tracer into a given teloblast early in embryogenesis and identifying its labeled descendants in older embryos (Weisblat et al., 1978, 1980a, b). In this manner, it has been shown that each kinship group has a stereotyped and unique distribution in the segment as a whole and within the segmental ganglion in particular. Since the identified neurons and glia of the ganglion are themselves stereotypically located in the ganglion (Muller et al., 1981), it can be inferred that each kinship group normally comprises a particular set of neurons and that in leech development neuronal cell lineage is highly determinate. This inference has derived support from the identification of a few of the cells that belong to a particular kinship group and the finding that in normal development they always arise from the same teloblast (Weisblat et al., 1980a, 1984; Blair, 1983; A. E. Stuart et al. manuscript in preparation). To assess the role of cell lineage in neuronal development further, we address here two questions raised by these earlier studies. First, how general is the principle of kinship group determinacy in neuronal lineage in normal leech development? Second, if kinship group determinacy in general, then do the neurons of a given kinship group have any common functional or morphological properties that set them 
apart from the members of the other kinship groups? To examine the first question, we ascertained the line of descent of a set of neurons. For that set we found that, in neuronal development in the leech kinship group, determinacy is a general phenomenon. As for the second question, no obvious common functional or morphological kinship group-specific properties could be identified.

\section{Materials and Methods}

Preparation of specimens for physiological identification of cells containing lineage tracer. Embryos of the giant glossiphoniid leech Haementeria ghilianii, obtained from our breeding colony (Sawyer et al., 1981), were used in most of these experiments. Although the related species Helobdella triserialis was used for previous lineage experiments and is used here for some of the experiments on the origin of glia, the small size of these embryos makes them unsatisfactory for physiological studies of developing neurons. On the other hand, the large size of the Haementeria embryo enables one to see lineage tracer within individual neurons of dissected, living embryos and allow the simultaneous anatomical and physiological identification of these neurons, using intracellular dye injections and electrical recordings.

A staging system used to characterize the development of glossiphoniid leeches has been detailed elsewhere (Weisblat et al., 1980a, 1984). The cleavage phase of early development (stages 1 to 6,0 to 2 days for Haementeria embryos at $27^{\circ} \mathrm{C}$ ) gives rise to bilateral pairs of teloblasts $\mathrm{M}, \mathrm{N}, \mathrm{O} / \mathrm{P}, \mathrm{O} / \mathrm{P}$, and $\mathrm{Q}$, which may be injected with lineage tracer early in stage 7 . During stages 7 and 8 the teloblasts, in turn, produce longitudinally arrayed bandlets of blast cells, which give rise to segmental complements of progeny cells, including segmental ganglion cells during stages 9 to 11 ( 10 to 40 days). Blast cells are produced one by one from the parent teloblast, and older blast cells give rise to more rostral segments. Thus, there is a caudal to rostral temporal progression of neurogenesis in stages 9 to 11 .

The procedures for injecting teloblasts in Haementeria with lineage tracer were the same as those previously reported (Weisblat et al., 1980a). The fluorescent rhodamine peptide tracer (RDP; Weisblat et al., 1980b) was injected in experiments where lineage tracer had to be visualized in cells of the living embryo. The RDP tends to clump into granules as it is distributed to progeny during development, so that cells containing this tracer often have just a few granules of it in the cytoplasm of the cell body. Teloblasts were injected with tracer shortly after their formation during stage 6 or 7 , and embryos were allowed to develop further. After neurogenesis, between late stage $y$ and middle stage 11, RDP-injected specimens were dissected and prepared as previously described (Kuwada and Kramer, 1983) for intracellular electrophysiological recordings under a compound microscope equipped with Nomarski differential interference contrast and epifluorescence optics. RDP fluorescence was located within particular neuron cell bodies, which were then impaled with microelectrodes filled with a $5 \%$ solution of fluorescent Lucifer Yellow dye. Dye was introduced into the cell by passage of 0.2 to $0.7 \mathrm{nA}$ of negative current for 0.5 to $2 \mathrm{~min}$ to reveal the cell's morphology, and electrophysiological recordings were taken. Photographs of neurons stained with lineage tracer and Lucifer Yellow were made in the unfixed, viable preparation. Drawings of neurons were made from the photographs. Rhodamine (RDP) fluorescence was observed using Zeiss filter set no. 487714; Lucifer Yellow fluorescence was observed using Zeiss filter set no. 487709; fluorescence excitation was provided by a 50 -Wmercury vapor lamp (Zeiss HBO 50) or a $100-\mathrm{W}$ tungsten halogen bulb. For histological studies, horseradish peroxidase (HRP) was used as the lineage tracer (Weisblat et al., 1978, 1984) HRP-injected specimens were prepared for histology as previously described (Weisblat et al., 1978)

\section{Results}

\section{Topography of kinship groups in the ventral nerve cord}

After a lineage tracer is injected into a teloblast of a stage 6 or 7 embryo, labeled cells appear arranged as segmentally repeating groups in the ganglia and body wall in the stage 9 to 11 embryo. We shall use the term kinship group to designate the set of cells within a ganglion that receives tracer from a particular teloblast. However, this group does not constitute a clone or a polyclone, because it does not include all of the descendants of the parent blast cell(s) (D. A. Weisblat and M. Shankland, manuscript in preparation).

Lineage-tracing experiments with the small glossiphoniid leech, Helobdella triserialis, have revealed that each of the five kinship groups is distributed with a unique and stereotyped topography in the juvenile ganglion (Weisblat et al., 1984). Since in the present work the assignment of identified neural cells to kinship groups was to be made in embryos of the giant leech Haementeria ghilianii, we first compared the topography of teloblast kinship groups in the ganglia of Helobdella and Haementeria. We found that the topography of each kinship group in Haementeria was nearly identical to that of the corresponding group in Helobdella (e.g., Figs. 2, 4A, and 5A may be compared with Fig. 2 in Weisblat et al., 1984). Moreover, as in Helobdella, each kinship group of Haementeria has a unique ganglionic distribution pattern that fits into the distribution pattern of the other kinship groups like the interlocking pieces of a jigsaw puzzle. This is evident in Figure 1, which shows a schematic presentation of kinship group topography in Haementeria.

The $\mathrm{N}$ kinship group occupies large regions on both dorsal and ventral aspects of the ganglion (Figs. 1 and $2 A$ ). Its cells appear to be distributed in several clusters, which are separated by narrow acellular regions or cellular regions derived from other teloblasts. The $\mathrm{O}$ kinship group is located in three regions (Figs. 1 and $5 A$ ): the dorsalmost region of the dorsal anterior cell packet, a narrow ventral strip along the anterior nerve tract, and two smaller clusters in the ventral posterior lateral cell packet. The cells of the $\mathrm{P}$ kinship group are confined to a ventral strip along the anterior nerve tract (Figs. 1 and $4 A$ ), except for one cell just posterior to this strip at the ventral midline of the ganglion. The $\mathrm{Q}$ kinship group consists of a single cell in this anterior nerve tract region, a few cells in the anterior part of the anterior medial cell packet on the ventral aspect, and some components of the connective nerve (Figs. 1, $2 B$, and $7 A$ ). Cells of the $\mathrm{M}$ kinship group are located between dorsal and ventral surfaces in the anterior lateral cell packet and are also present in the connective (Fig. 1).

The size of each kinship group evidently increases with the proximity of its progenitor germinal bandlet to the ventral midline of the embryo. Thus, the $\mathrm{N}$ kinship group, whose bandlet lies next to the ventral midline, is the largest and the Q kinship group, whose bandlet lies furthest from the ventral midline, is the smallest. The mesodermal (M) kinship group is even smaller than the $Q$ group.

The similarity in kinship group size and distribution between Helobdella and Haementeria, together with the similarities in position of various identified neurons in the two species, is taken as justification for the occasional extrapolation from one species to the other in the analysis of cell lineage data.

\section{Kinship groups of identified cells}

To assess whether the stereotyped topography of kinship groups in the segmental ganglion reflects a determinate lineage of neuronal cells, we determined the extent to which a given identified neuron invariably originates from the same teloblast. The techniques used for this study are illustrated in Figure 3. A teloblast was injected with RDP in an early stage 7 embryo and the embryo was dissected at stage 10 or 11 , by which time the mechanosensory neurons have differentiated and are identifiable. If RDP fluorescence was seen to be localized within a putative mechanosensory neuron, identified by size and position of its cell body in the ganglion (Fig. $3, A$ and $C$ ), the identity of the neuron was confirmed by injecting its cell body with Lucifer Yellow dye (Fig. 3B) and by taking intracellular electrophysiological recordings. In this way, mechanosensory neurons could be identified unambiguously by their morphology and physiology, as previously described (Kuwada and Kramer, 

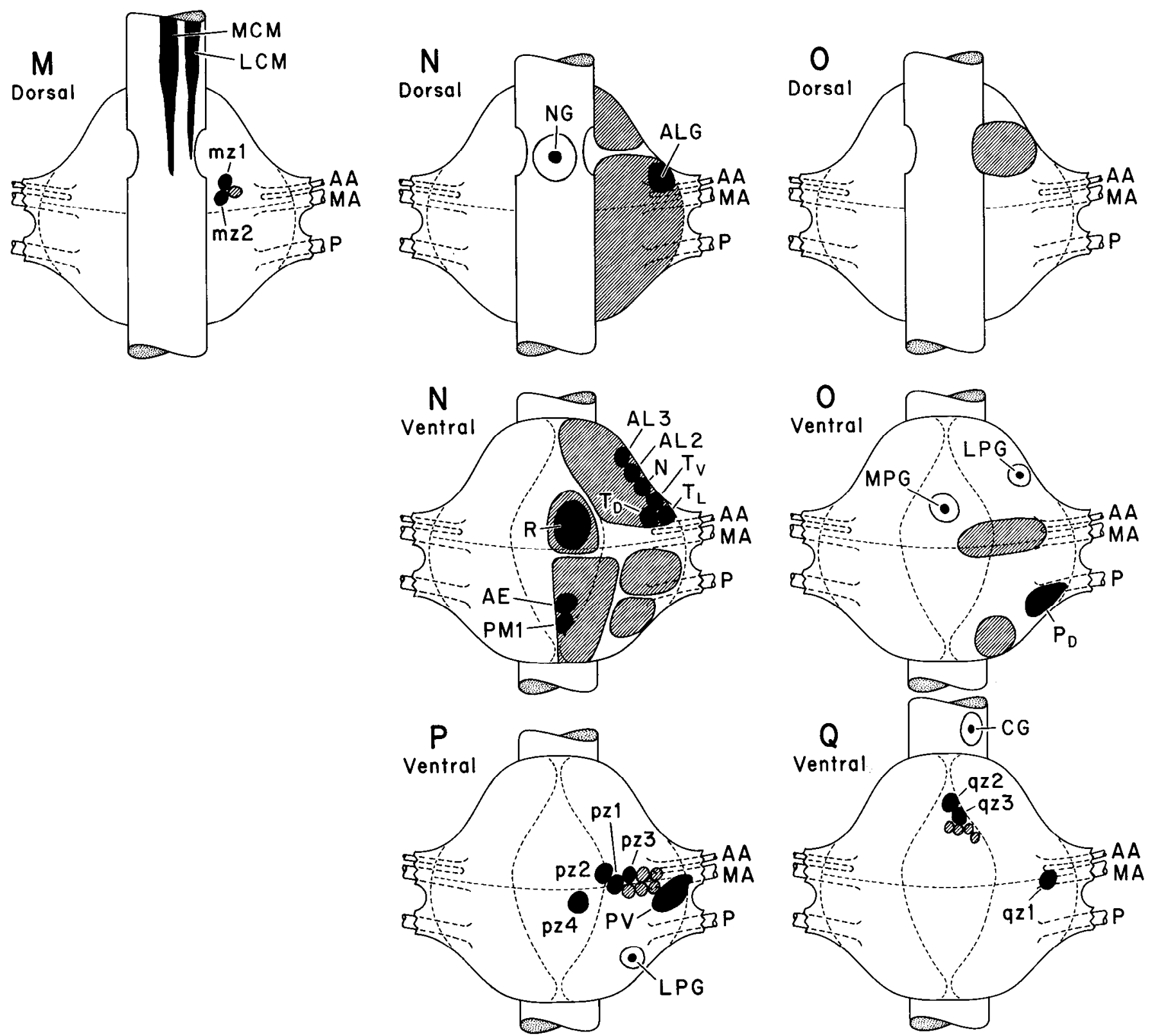

Figure 1. Schematic presentation of the topography of kinship groups in a Haementeria ghilianii segmental ganglion. The $\mathrm{N}$ and $\mathrm{O}$ teloblast kinship groups occupy both dorsal and ventral aspects of the ganglion; $\mathrm{P}$ and $\mathrm{Q}$ are confined to the ventral aspect; $\mathrm{M}$ is divided between the dorsal aspect of the connective and the center of the half-ganglion, midway between dorsal and ventral aspects. Anterior is up in this and all other figures. The connective nerve tracts traverse the ganglion on its dorsal aspect, and three peripheral nerves (AA, MA, and P) issue from the sides of the ganglion. Boundaries of cell packets, each of which is associated with a packet glial cell, are indicated by dashed lines. The locations of cells in each kinship group are indicated as follows: large cross-hatched regions in $N$ and $O$ are clusters of uncounted cells; crosshatched circles in $M, P$, and $Q$ are cell bodies of single, unidentified neurons; solid circles with labels are cell bodies of identified neurons; open circles enclosing a small solid circle are nuclei of glial cells; and MCM and LCM are the medial and lateral connective muscle cells, respectively. The neuropil glial cell body is at the ventral edge of the neuropil. The clusters of $\mathrm{N}$ group cells in the dorsal anterior region of the ganglion are ventral to the dorsal anterior cluster of $\mathrm{O}$ group cells. Cell abbreviations are defined in the legend of Table II. The precise numbers of neurons indicated for the M, P, and Q kinship groups represent our best estimates, subject to undetermined error from several sources (see the text).

1983). We were able to confirm the presence of RDP within the cell body that had been injected with Lucifer Yellow because, after a minute or two of illumination under conditions used to reveal Lucifer Yellow fluorescence, a change in spectral properties of the injected cell ensues so that cell bodies containing Lucifer Yellow dye also fluoresce under the conditions used to observe RDP fluorescence. As a result of this phenomenon, to which we refer as Lucifer-induced red fluorescence, the distribution of both RDP and Lucifer Yellow can be detected with the same filter set. The two dyes can still be distinguished from one another, however, by their distributions within the cell. Lucifer Yellow fluorescence is emitted relatively weakly but uniformly from the entire cell body, whereas the RDP fluorescence appears as much brighter, localized fluorescent granules (Fig. $3 B$ ). Thus, an identified cell body injected with Lucifer Yellow was determined to contain RDP tracer if, under the fluorescence microscope, RDP granules could be seen within the cell boundaries outlined by the Lucifer-induced red fluorescence.

One group of functionally and structurally related ganglionic neurons, whose teloblasts of origin we examined by this technique, comprises the six pairs of mechanosensory neurons, which have been well characterized in the adult (Nicholls and Baylor, 1968; Kramer and Goldman, 1981) and embryonic 

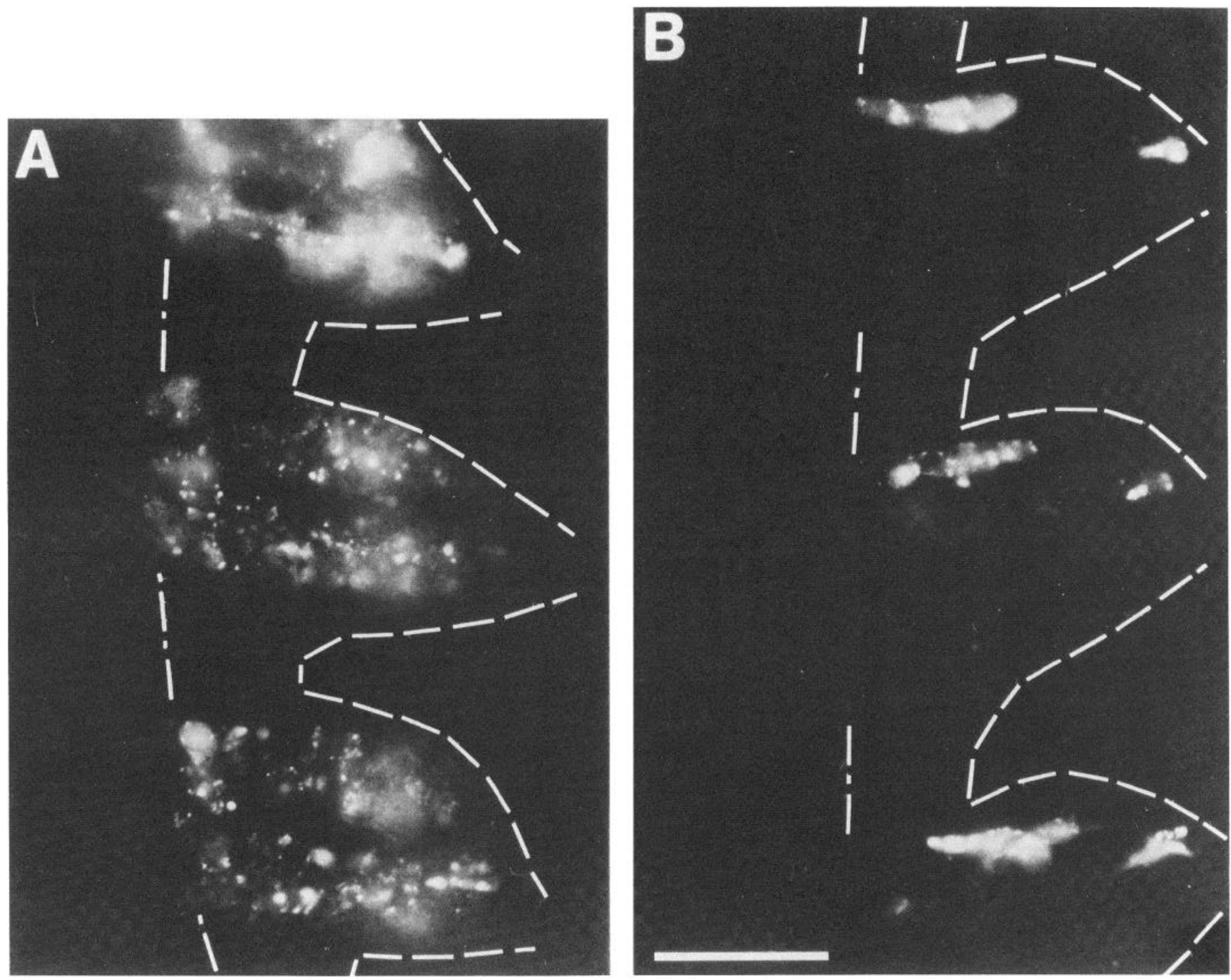

Figure 2. Distribution patterns of teloblast lineage tracer in the ventral nerve cord of Haementeria ghilianii shown in fluorescent photomicrographs of RDP on the ventral aspect of a three-ganglion chain. A, Early stage 11 embryo whose right $\mathrm{N}$ teloblast was injected with RDP at stage 7. RDP is located in cells of the right hemiganglion only. In this and other similar photographs, the hemiganglion outlines are shown as dashed lines and the midline of each connective is shown as a dash-dot line. RDP is distributed within a cell body both as a faint uniform fluorescence and as one or more bright, variable sized granules. RDP granules are usually excluded from the nucleus of a cell. $B$, Early stage 10 embryo whose right $\mathrm{Q}$ teloblast was injected. The $\mathrm{Q}$ contribution to the connectives in this same chain of ganglia is presented in Figure $7 A$. Note that locations of cell clusters in each ganglion are regions lacking RDP in ganglia of $A$. Scale bar, $50 \mu \mathrm{m}$.

(Kramer and Kuwada, 1983; Kuwada and Kramer, 1983) leech. These include the dorsal, ventral, and lateral "touch" neurons $\left(\mathrm{T}_{\mathrm{D}}, \mathrm{T}_{\mathrm{V}}\right.$, and $\left.\mathrm{T}_{\mathrm{L}}\right)$; dorsal and ventral "pressure" neurons $\left(\mathrm{P}_{\mathrm{D}}\right.$ and $\mathrm{P}_{\mathrm{V}}$ ); and the "nociceptive" neuron $(\mathrm{N})$. Results of this examination are presented in Table I, from which it is evident, first, that the lineage of the mechanosensory neurons is highly determinate and, second, that these neurons belong to different kinship groups. The most carefully studied neurons were the pressure neurons, $\mathrm{P}_{\mathrm{D}}$ and $\mathrm{P}_{\mathrm{V}}$. Label was seen in the cell body of all 24 ipsilateral $P_{V}$ neurons examined in specimens in which a generative $\mathrm{P}$ teloblast had been injected with RDP (Fig. 3). However, with one exception, tracer from the RDP-injected P teloblast was not found in the cell bodies of $9 \mathrm{P}_{\mathrm{D}}$ neurons examined (Fig. 4). (This one exception will be considered in the "Discussion.") Tracer was found in the cell bodies of all 9 ipsilateral $P_{D}$ neurons examined in specimens in which a generative $O$ teloblast had been injected with RDP (Fig. 5). Our results thus indicate that the $P_{D}$ and $P_{V}$ neurons belong to different kinship groups, with the $P_{D}$ neuron belonging to the
$\mathrm{O}$ group and the $\mathrm{P}_{\mathrm{v}}$ neuron to the $\mathrm{P}$ kinship group. Furthermore, neither $P_{D}$ nor $P_{v}$ neurons were ever found to belong to the $M$, $\mathrm{N}$, or $\mathrm{Q}$ kinship group (Table I, Fig. 5).

Similar experiments showed that the other mechanosensory neurons, $\mathrm{T}_{\mathrm{V}}, \mathrm{T}_{\mathrm{D}}, \mathrm{T}_{\mathrm{L}}$, and $\mathrm{N}$, belong to the $\mathrm{N}$ kinship groups. All of the $\mathrm{T}$ and $\mathrm{N}$ neurons that were identified physiologically and examined in specimens whose $\mathrm{N}$ teloblast had been injected with RDP contained tracer (Fig. 6). Conversely, none of the T or $\mathrm{N}$ neurons contained tracer in embryos of which any of the other four teloblasts had been injected (Table I).

Lineage of glial cells. Another group of functionally and structurally related ganglion cells whose teloblasts of origin we examined consists of the giant glial cells (Kuffler and Potter, 1964). There are five pairs of such glial cells in each ganglion: neuropil glial cells, which straddle the midline in the center of the ganglion and wrap cell processes in the neuropil; the connective glial cells located in the center of the lateral connective nerve tracts, which wrap cell processes in the connective; and three pairs of packet glial cells, a ventromedial pair, an antero- 


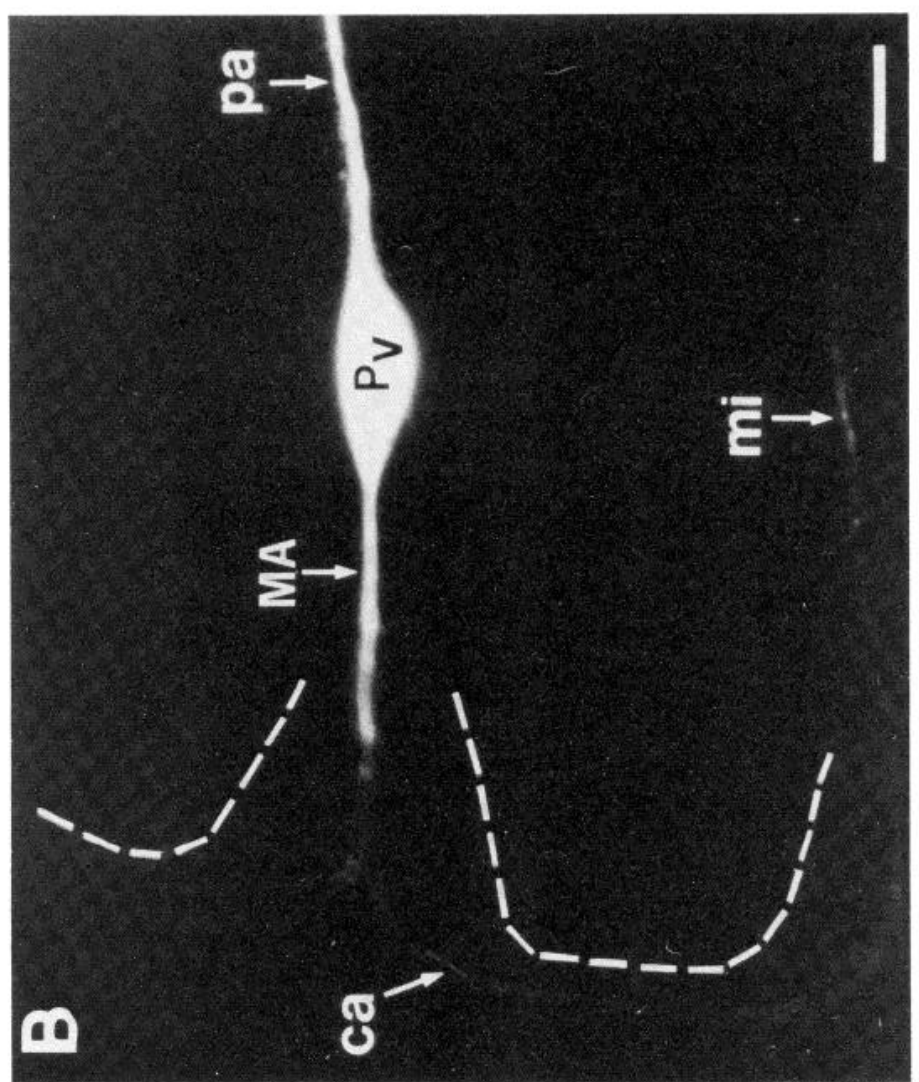

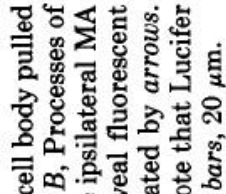
ธิ ङ

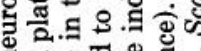

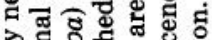
원원

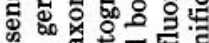
융 ฮై 过

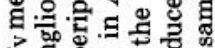

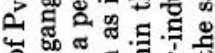
政 击击

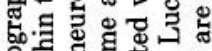
范口䟢 ह वण

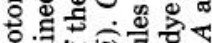

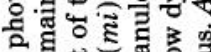

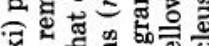

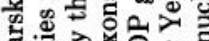

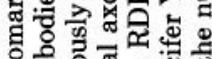
的 ¿

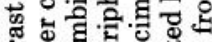
편 ⿷匚ّ 이의

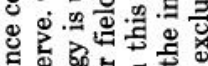

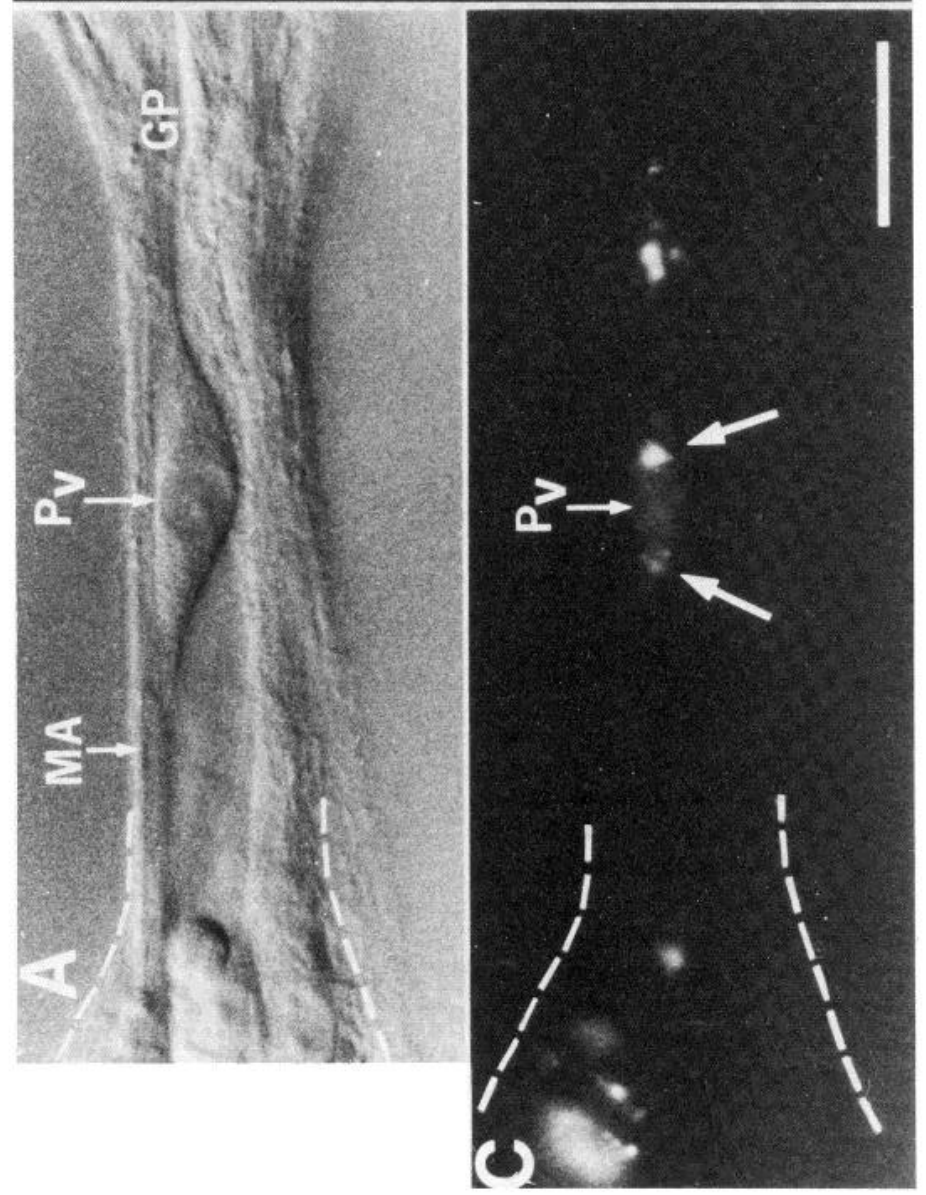

현응응. 도요

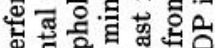

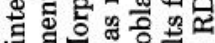

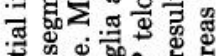

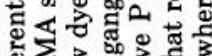

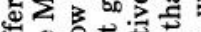

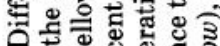

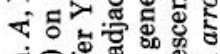
ह่ $\widehat{0}$ ㅇํㄹ월

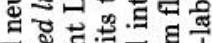

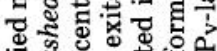

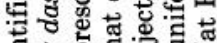

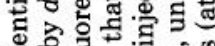

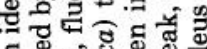
๘

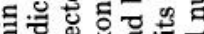

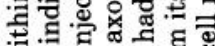
5. 젼

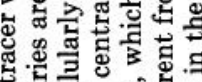
急

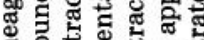

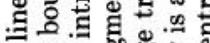
낭 흥ㅎㅀ 웡 б

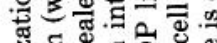

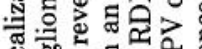

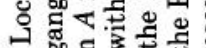
ஸ \&范

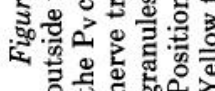


TABLE I

Teloblast of origin of identified mechanosensory neurons

\begin{tabular}{|c|c|c|c|c|c|c|c|c|c|c|c|c|}
\hline \multirow{3}{*}{$\begin{array}{l}\text { Teloblast } \\
\text { Labeled }\end{array}$} & \multicolumn{12}{|c|}{ Neurons Labeled } \\
\hline & \multicolumn{2}{|c|}{$\mathrm{T}_{\mathrm{V}}$} & \multicolumn{2}{|c|}{$\mathrm{T}_{\mathbf{L}}$} & \multicolumn{2}{|c|}{$\mathrm{T}_{\mathrm{D}}$} & \multicolumn{2}{|c|}{$\mathrm{N}$} & \multicolumn{2}{|c|}{$\mathrm{P}_{\mathrm{D}}$} & \multicolumn{2}{|c|}{$\mathrm{P}_{\mathrm{v}}$} \\
\hline & Percentage ${ }^{a}$ & $\begin{array}{c}(n, z) \\
X\end{array}$ & Percentage & $\begin{array}{c}(n, z) \\
X\end{array}$ & Percentage & $\begin{array}{c}(n, z) \\
X\end{array}$ & Percentage & $\begin{array}{c}(n, z) \\
X\end{array}$ & Percentage & $\begin{array}{c}(n, z) \\
X\end{array}$ & Percentage & $\begin{array}{c}(n, z) \\
X\end{array}$ \\
\hline $\mathrm{N}^{b}$ & 100 & $(2,2) 1$ & 100 & $(2,2) 1$ & 100 & $(4,4) 3$ & 100 & $(5,5) 3$ & & & & \\
\hline $\mathrm{O}^{\circ}$ & 0 & $(6,0) 1$ & 0 & $(6,0) 1$ & 0 & $(6,0) 1$ & 0 & $(6,0) 1$ & 100 & $(9,9) 2$ & 0 & $(2,2) 1$ \\
\hline $\mathbf{P}^{c}$ & 0 & $(16,0) 3$ & 0 & $(16,0) 3$ & 0 & $(16,0) 3$ & 0 & $(16,0) 3$ & 10 & $(9,1) 5$ & 100 & $(24,24) 8$ \\
\hline
\end{tabular}

${ }^{a}$ Percentage of neurons examined that are labeled; $n$ is total number of neurons examined (including those examined visually only), $z$ is number of neurons examined and identified physiologically, and $X$ is number of specimens examined.

${ }^{b}$ The distribution of neurons labeled after $\mathrm{Q}$ and $\mathrm{M}$ teloblast injections were so distant from the location of the cell bodies of the $\mathrm{P}$ neurons (which can be identified in the embryo just by their size and position (Kuwada and Kramer, 1983)) that, in most cases, a simple visual examination under Nomarski optics were sufficient to determine that the tracer from these teloblasts was not located in the $\mathbf{P}$ neurons. The $\mathbf{P}$ neurons were not examined in specimens bearing labeled progeny of an injected $\mathrm{N}$ teloblast.

' The distribution of lineage tracer from these teloblasts was so distant from the ' $\mathrm{l}$ ' and $\mathrm{N}$ neuron cell bodies (which usually can be identified by size and position alone) that the absence of tracer could be determined by visual examination.

lateral pair, and a posterolateral pair, which wrap neuron cell bodies in the corresponding cell packets of the ganglion.

It is known that the giant neuropil glial cell pair of IIelobdella is derived from the $\mathrm{N}$ teloblast (Weisblat et al., 1980a; Blair and Weisblat, 1982). We have now studied the origins of packet glial cells in Helobdella by lineage-tracing experiments, using HRP injections of teloblasts and histological examination of sectioned nerve cords. The criteria for identification of a packet glial cell in sectioned material were the stellate contour of the glial cell body and its superficial location within the packet of the stage 10 embryo (Fig. 7). However, packet glia are not unambiguously recognizable by these criteria. Of nine serially sectioned, O-labeled ganglia examined, each of eight contained two labeled cells identified by these criteria as packet glia, one anterolateral and one ventromedial glial cell in each. Only one packet glial cell, located ventromedially, was recognized in the remaining ganglia. Similarly, in two of seven serially sectioned, P-labeled ganglia similarly examined, no labeled glia were recognized. The remaining five ganglia each appeared to contain a labeled posterolateral glial cell. We assume that this variability in the apparent number of labeled glia reflects the difficulty in identifying packet glia, labeled or unlabeled, and not a true variability in their occurrence. We conclude that, of the six packet glia in each ganglion, the ventromedial pair and the anterolateral pair normally derive from the two $\mathrm{O}$ kinship groups, and the posterolateral pair normally derives from the two P kinship groups.

The connective glia are derived from the $Q$ teloblast, as determined both in Helobdella and in Haementeria. The connective glial cells in each segment of the adult nerve cord originate developmentally as a single pair of founder cells located between adjacent ganglia ventral to the lateral connective nerve tracts in stage 9 embryos (A. P. Kramer, unpublished observations). (In Helobdella, these founder cells divide once, giving rise to the adult number of two glial cells in each half of the interganglionic connective (Weisblat et al., 1980a), but in Haementeria, progeny of the founder cells undergo additional rounds of division so that as many as 32 glia cell bodies per half-connective can be observed in a stage 11 Haementeria embryo (A. P. Kramer, unpublished ohservations).) These founder cells were labeled in stage 9 Haementeria embryos whose $\mathbf{Q}$ teloblast had been injected with RDP at early stage 7 (Fig. 8). The connective glial cells were easily identified by injecting one of them with Lucifer Yellow dye, which spreads to all other glial cells in the nerve cord, presumably via gap junctions, resulting in a highly characteristic pattern of ganglion staining
(Fig. $8 B$ ). In whole mounts of stage 11 Helobdella embryos whose right $Q$ teloblast had been injected with $\mathrm{HRP}$ at early stage 7 , labeled connective glia were recognized as labeled, longitudinally oriented processes whose width spanned the ipsilateral connective (not shown).

It appears, therefore, that, just as is the case for the mechanosensory neurons, the functionally and structurally related glial cells do not all belong to the samc kinship group. Instead, each of the ectoteloblast kinship groups contains at least one glial component. These results are presented quantitatively in Table II and schematically in Figure 1.

\section{Types of CNS neurons in teloblast kinship groups}

Although the group of mechanosensory neurons is spread over three and the group of glial cells over four different kinship groups, there may be other groups of neurons, for example, those whose cells share a similar morphology, that do fall into a single kinship group. To explore the possibility that neurons of particular morphological types are lineally segregated, we identified many additional ganglionic neurons in each kinship group and characterized the morphology of some neurons that were hitherto unknown. For this purpose, neurons of RDPlabeled embryos were identified morphologically by injecting them with Lucifer Yellow and were assigned to one of the five kinship groups. A morphologically identified neuron was not assigned to a kinship group unless it had been found several times to contain lineage tracer derived from the same teloblast. As was the case for the mechanosensory neurons, each of the 14 identified neurons examined in these experiments was always found in a particular kinship group. However, the possibility that a given neuron might occasionally arise in a different kinship group was not excluded as rigorously in these cases as in the case of the mechanosensory neurons. The results of this survey are presented in Table II.

Because there are so few of them, we were able to estimate the number of neurons in the $P, Q$, and $M$ kinship groups by counting the total number of RDP-labeled cells: 8 to 12 neurons in P, 6 to 9 neurons in $Q$, and 3 to 6 neurons in $M$. (Because of the granularity of the lineage tracer and because of its presence in glia, it was impossible to be sure whether a given cell contained label without injection of Lucifer Yellow, and we could never be certain that all tracer-labeled cells in a given ganglion had been found. Moreover, although some identified neurons are present in all midbody ganglia, others are present only in certain ganglia (Muller et al., 1981), and careful counting has revealed an apparently random variation in the total 


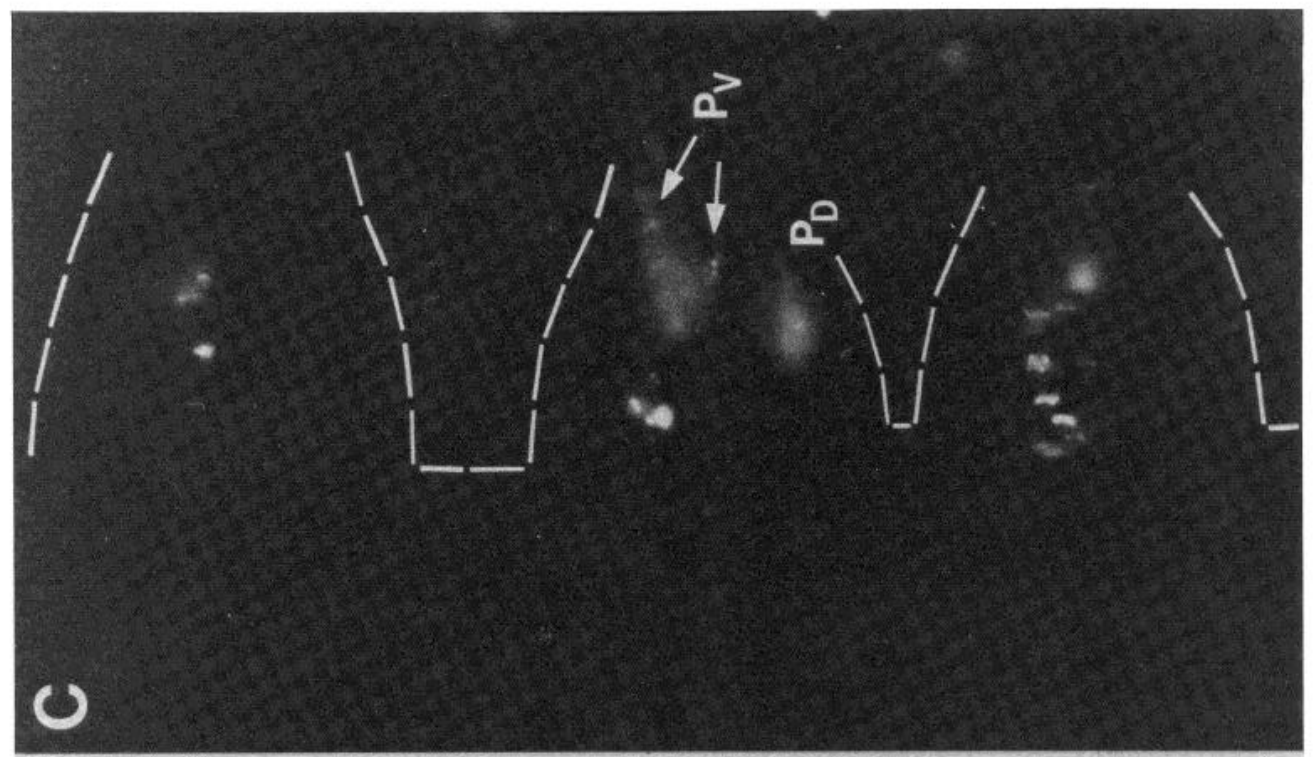

๘ี

ษั

㱐恋

ีㅡㄹ

声

을 힐

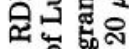

范 की

도월

式氙

न

急完

bo 3

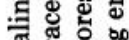

㽦它吉

证

도옳.

'

을 공

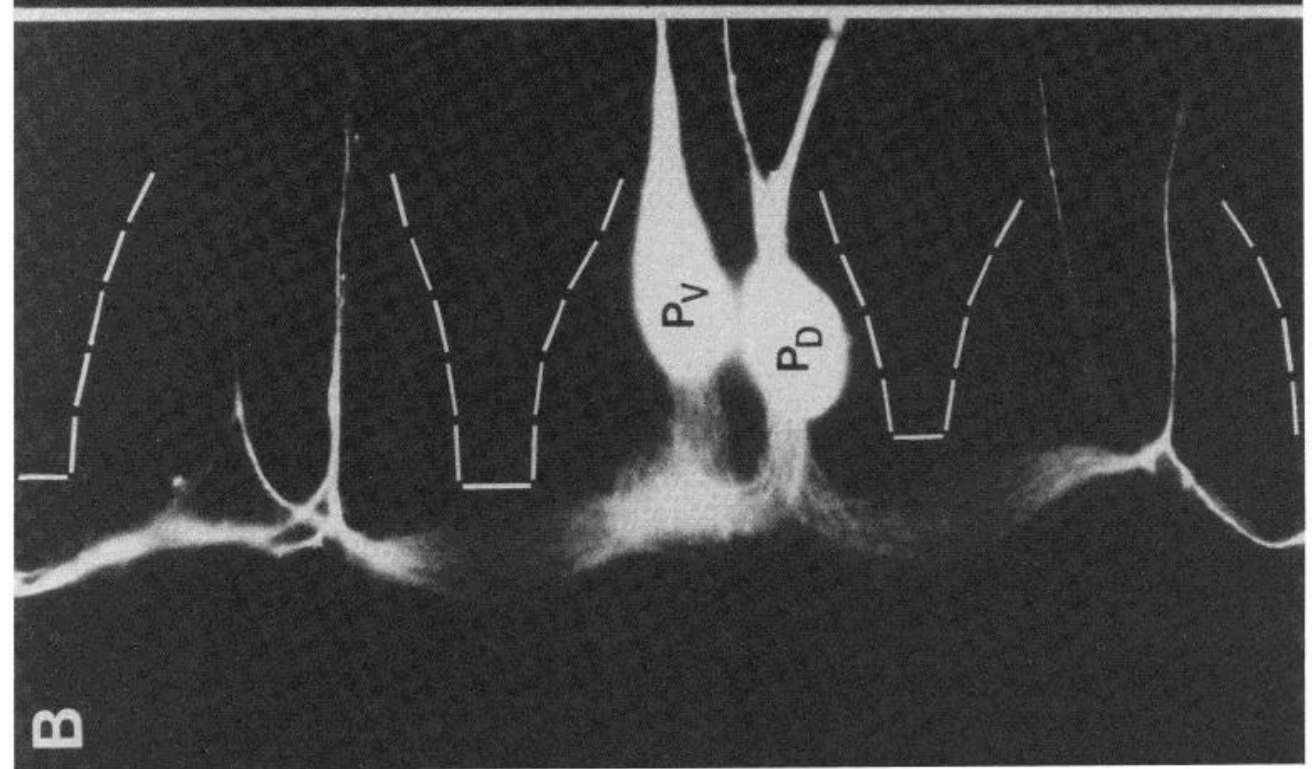

क.

㑒总

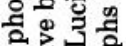

노용

\&

눈형

压完品

مी

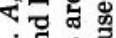

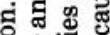

2

\&

त्ञ

唝.

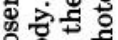

응

궁

屯요

की

형음

志涪?

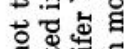

व

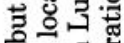

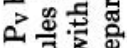

豆

ॠ

인를

品

क्षि

is 능

당

要过

․ㅗㅇ.

응.

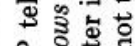

中 논⿺ㅝㄹ

¿元节

क्ष

空

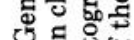



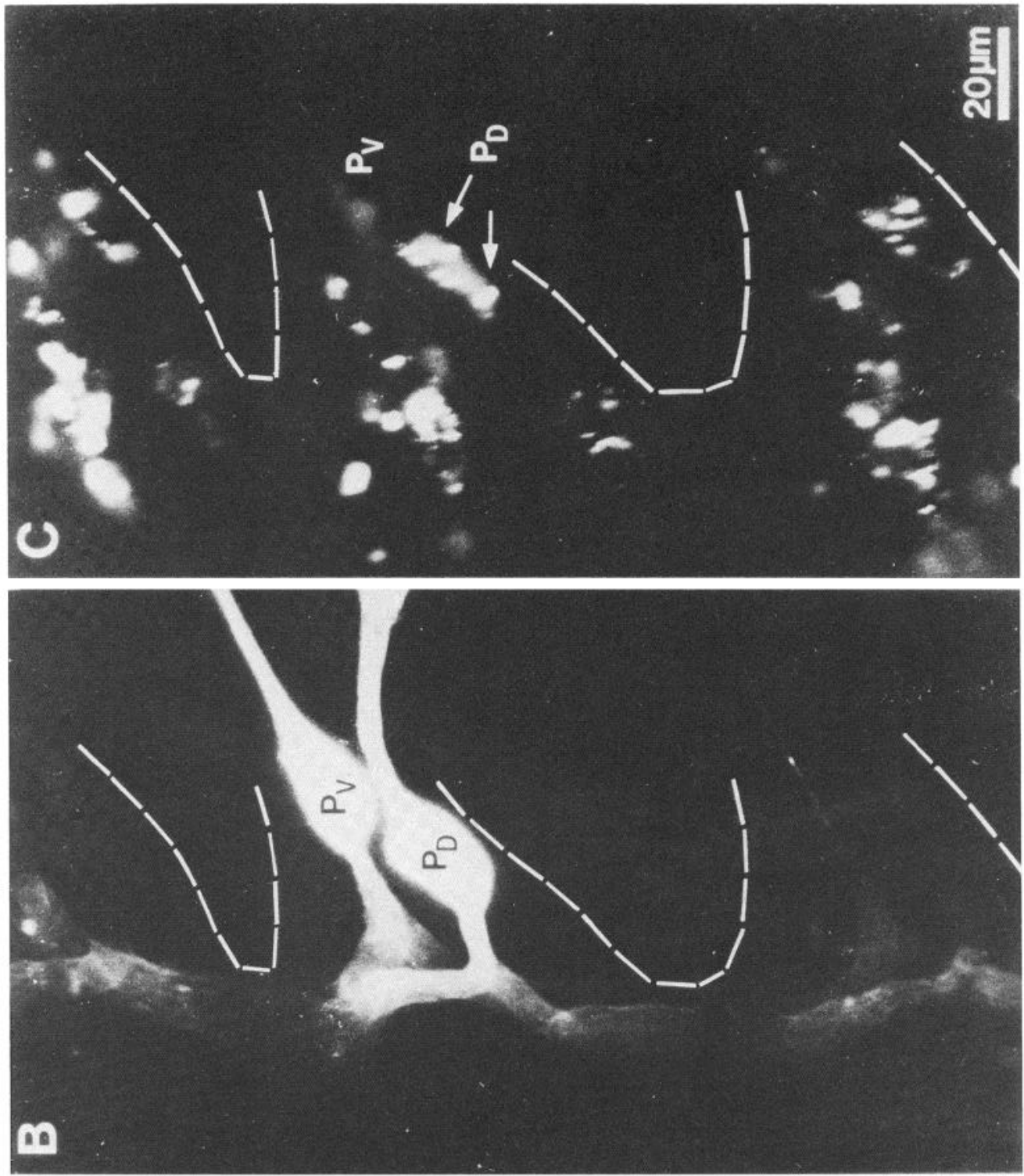

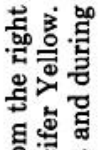

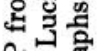

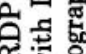

象

당

ᄃ워

ב.

至

.

४宗

द

ब묘

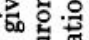

.

능

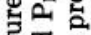

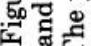

I $>$

के

क ष है

둘요

承的

ㅁํㄹ

.

政

s. .

츨

क

द्व

ธิ

政

항

>ㅇ.?

ํㅜㅇ

एँ

哰

สํㅀ 푸

s. 명

>

م.

옹

\$

웡

.

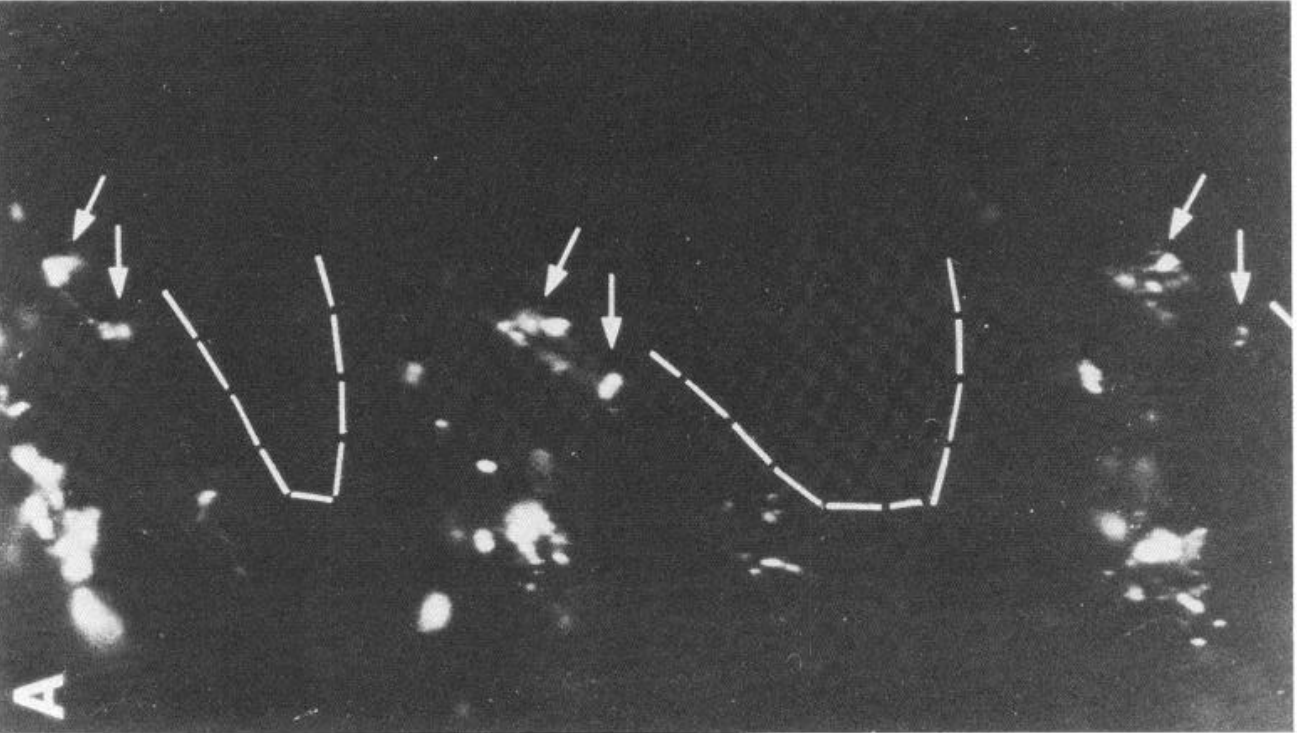

כ)

م

车父

ᄋ.

. 동

ज

용ํㄹ

品

亜

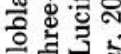

ذ)

유률

落 क

⿷匚⿱

응형

ष

की 용

․․

今

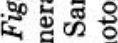
吠比 


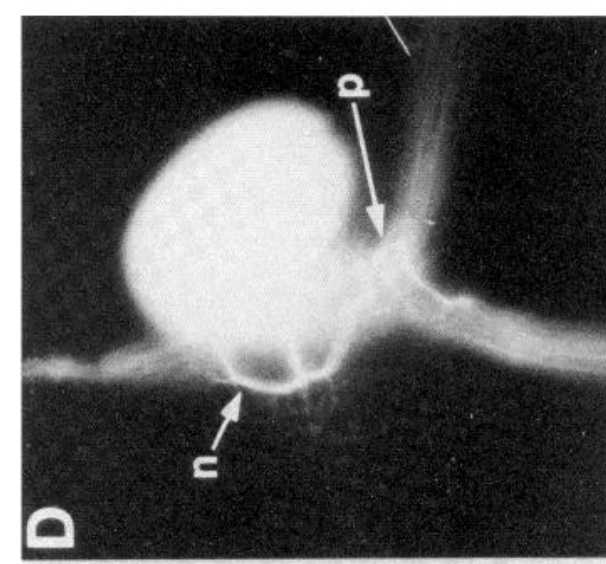

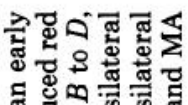

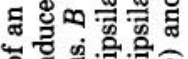

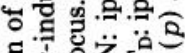
ร

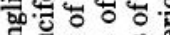

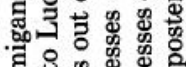
요. 0

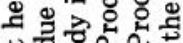
势

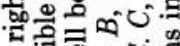
का

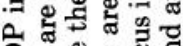
定范

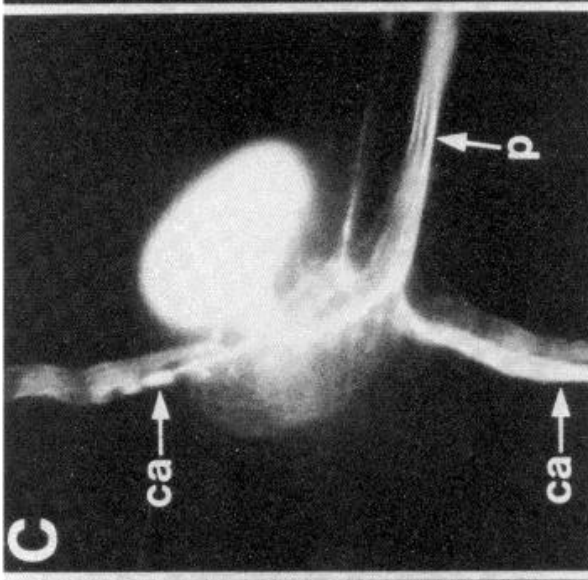
ส 공은

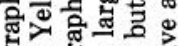
응

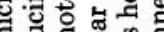

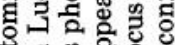
돈.

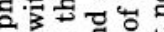
붕. 또 政

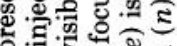

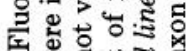
४

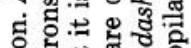

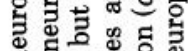

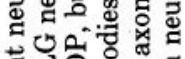
सु

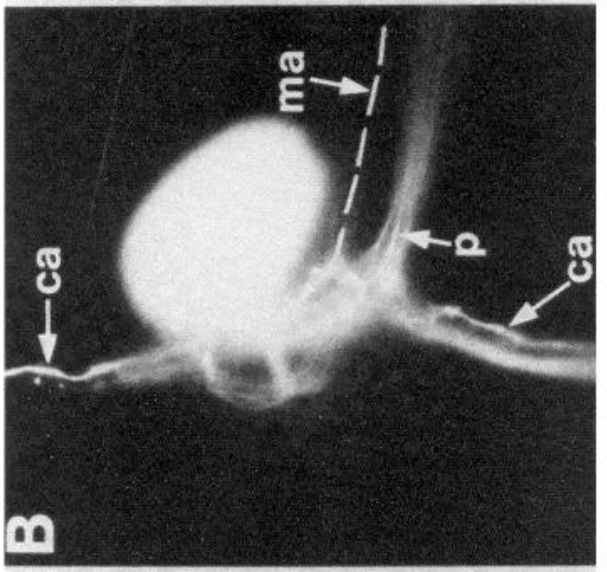
कo क. है

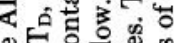

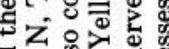
등

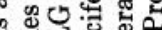
c) 누의

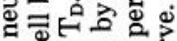
ㄱㅠㅁㅀㅀ मे का है

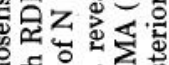
麦宊

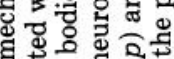
.

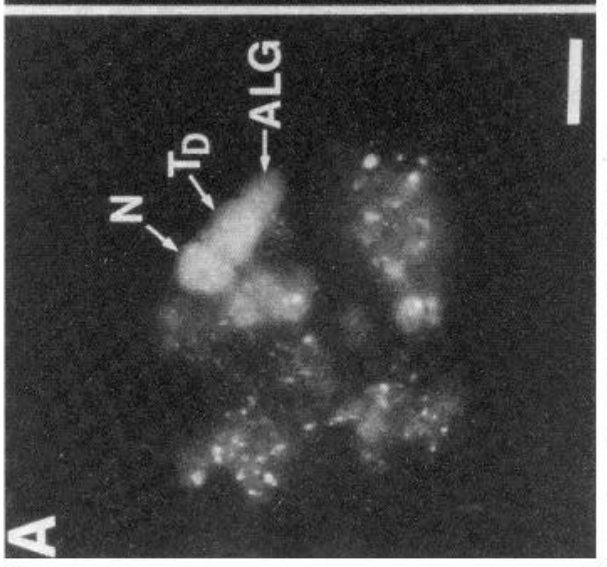
몽. 눤 吨.

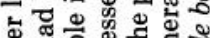

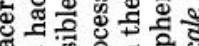
政零

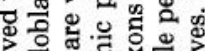
过 के ⿷ . 융 $\Phi$ 呈 $\mathrm{Z}$ 서엉 ० है

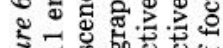

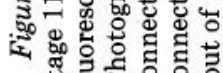




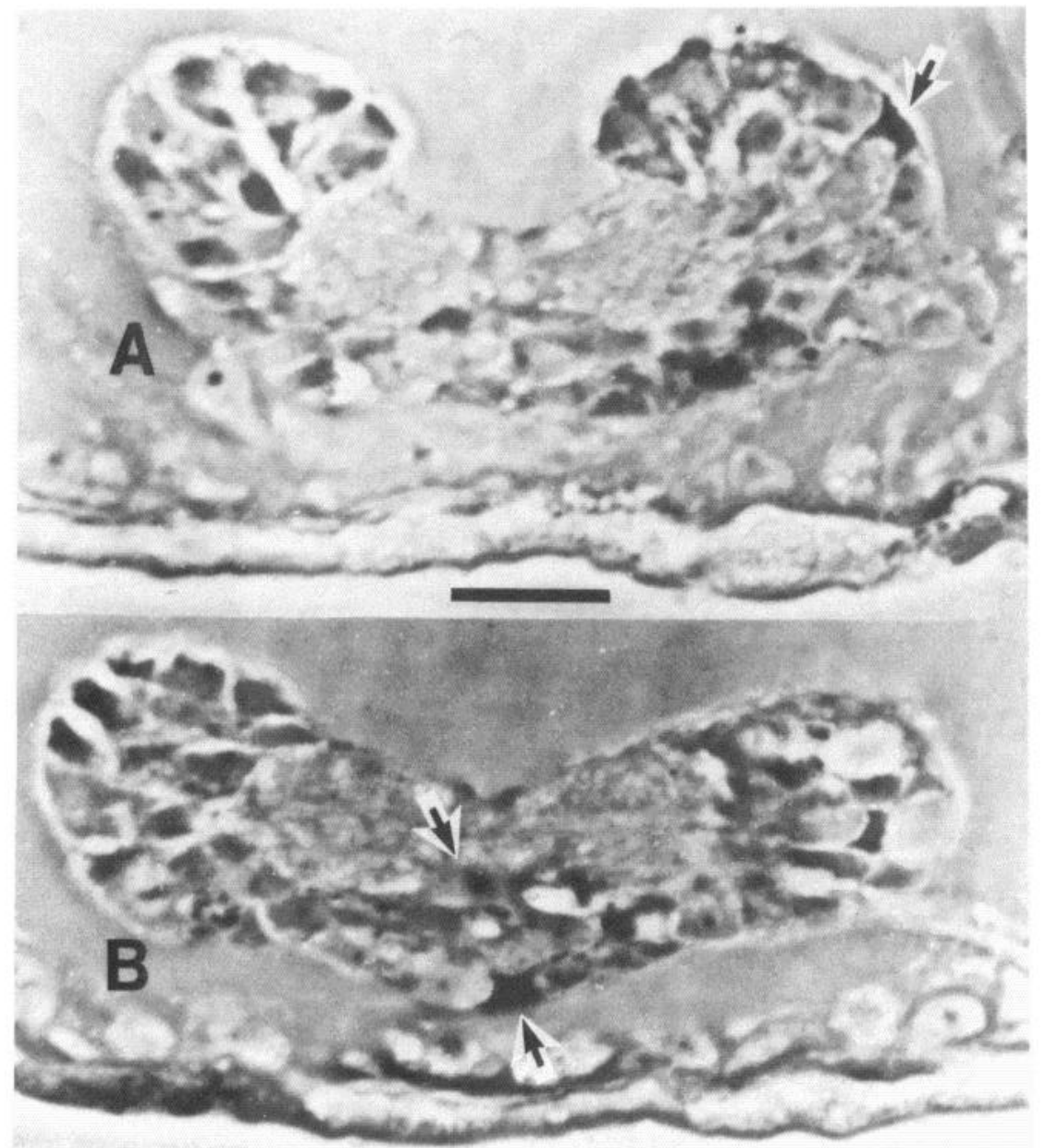

Figure 7. HRP-labeled packet glia in segmental ganglia of Helobdella triserialis. Transverse $3-\mu \mathrm{m}$ sections through the nerve cord of a stage $10 \mathrm{em}$ bryo in which a generative $O$ teloblast had been injected with HRP early in stage 7. A, The arrow indicates a putative anterolateral packet glia, identified as such by its stellate contour and location at the margin of the anterior part of the stage 10 ganglion. Similar labeled cell profiles are seen in the posterior part of ganglia from embryos in which a generative $\mathrm{P}$ teloblast has been injected. $B$, The lower arrow indicates a putative ventromedial packet glia, which is labeled only when a generative 0 teloblast has been injected. The upper arrow indicates an unlabeled neuropil glial cell. The nuclei and nucleoli of the labeled cells are obscured in this photograph by the HRP reaction product. Scale bar, $10 \mu \mathrm{m}$.

number of neurons even between homologous ganglia from different individuals (Macagno, 1980). Thus, the range of values for the size of these kinship groups results from an as yet unresolved mixture of experimental indeterminacy, systematic differences in kinship group size between different segments, and developmental noise.) Since only two specimens with an injected $\mathrm{O}$ teloblast were examined, our estimate of the number of cells in the $\mathrm{O}$ kinship group is more approximate, namely, 20 to 50 neurons. The neurons in the $\mathrm{N}$ kinship group are too numerous to count; the estimated value of 130 to 160 neurons in that group derives from the number of neurons in the halfganglion that are not members of the other teloblast kinship groups. The types of neurons that were found in each teloblast kinship group are discussed below.

Neurons of the $N$ kinship group. Of the 130 to 160 neurons in this group, 4 are the mechanosensory neurons $T_{V}, T_{L}, T_{D}$, and $\mathrm{N}$; at least 10 others are also afferent and efferent neurons, including some presumptive motor neurons (whose processes exit from the ganglion via the contralateral segmental nerve); and the remainder (about 100 neurons) are probably interneurons (Table II). Previously identified neurons that were found in the $\mathrm{N}$ kinship group include the anulus erector motor neuron, AE (Stuart, 1970; Kramer and Goldman, 1981); the Retzius cell, a giant serotonergic effector neuron probably found in all leech species (Lent, 1977); the anterior lateral giant (ALG) neuron (Fig. 6), a neuron with peripheral axonal projections of unknown function that is specific to glossiphoniid leeches (Kramer and Goldman, 1981); the PM1 neuron, apparently homologous to the peripherally projecting "nut" of Hirudo medicinalis (Kramer and Goldman, 1981; Muller et al., 1981), located near the AE neuron; and a contralaterally exiting neuron near the
$\mathrm{T}$ and $\mathrm{N}$ cells, designated as AL2 (with axons in the contralateral MA and $\mathrm{P}$ peripheral nerves and in the anterior and posterior contralateral connective). The ganglionic location of these and the other identified cells in the $\mathrm{N}$ kinship group is shown in Figure 1. It is possible that all motor neurons belong to the $\mathrm{N}$ kinship group (J. Braun, personal communication), but we cannot rule out the possibility that some are also derived from the $\mathrm{O}$ teloblast. Thus, a large variety of neuron types are represented in the $\mathrm{N}$ kinship group, and no neuronal characteristic unique to the $\mathrm{N}$ kinship group has so far emerged, except that all of the serotonin-containing neurons derive from the N teloblast (see "Discussion").

Neurons of the $O$ kinship group. Because an $\mathrm{O}$ kinship group was successfully labeled in only two embryos, it was not possible to characterize many of its members except that, as shown above, it includes the $\mathrm{P}_{\mathrm{D}}$ mechanosensory neuron and two packet glial cells. Some of its other members are interneurons (Table II).

Neurons of the $P$ kinship group. Of the 8 to 12 neurons in this group, most, if not all, were examined by injections of Lucifer Yellow dye (Fig. 9). Except for the $\mathrm{P}_{\mathrm{v}}$ mechanosensory neuron, all other $\mathrm{P}$-derived neurons in the ganglion appear to be interneurons (Table II). Most of these are of similar morphology: all project axons through several segments anteriorly in the ipsilateral connective nerve, and most also project axons into the posterior ipsilateral connective ("Ipsilateral A" and "Ipsilateral A \& P" in Table II). All of these neurons exhibit rather sparse neuropilar processes confined to a narrow region of the neuropil near the connective nerve tracts in the ganglion (Figs. 10 and 11). It is possible that the sparse neuropilar processes apparent in stage 11 embryos are not representative 

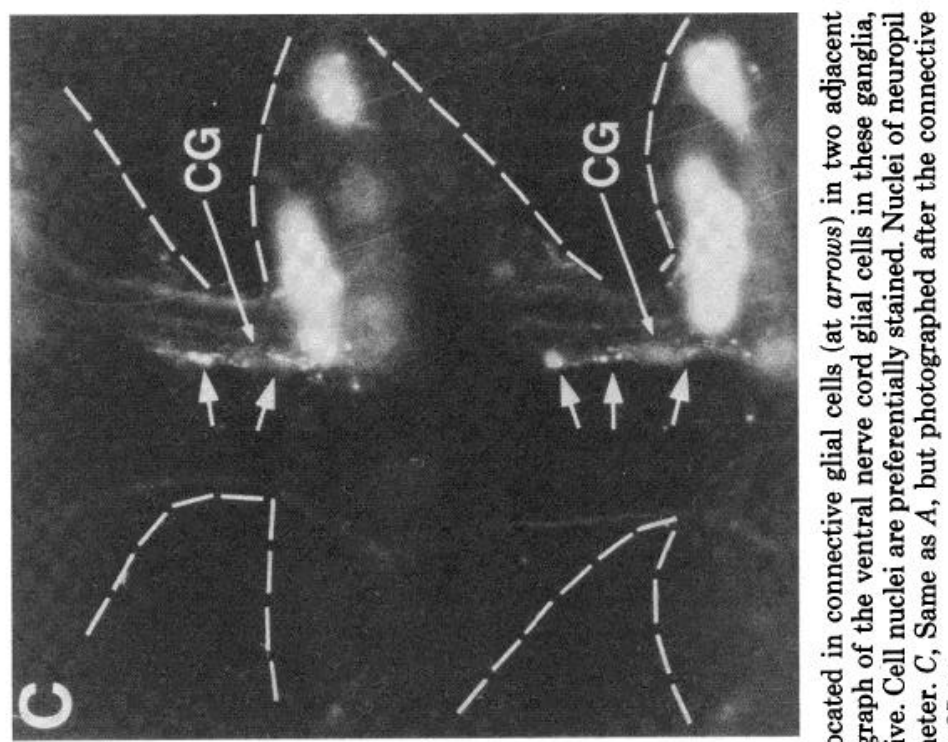

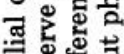

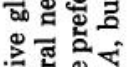

势

हैं

ठ욜

专

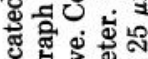

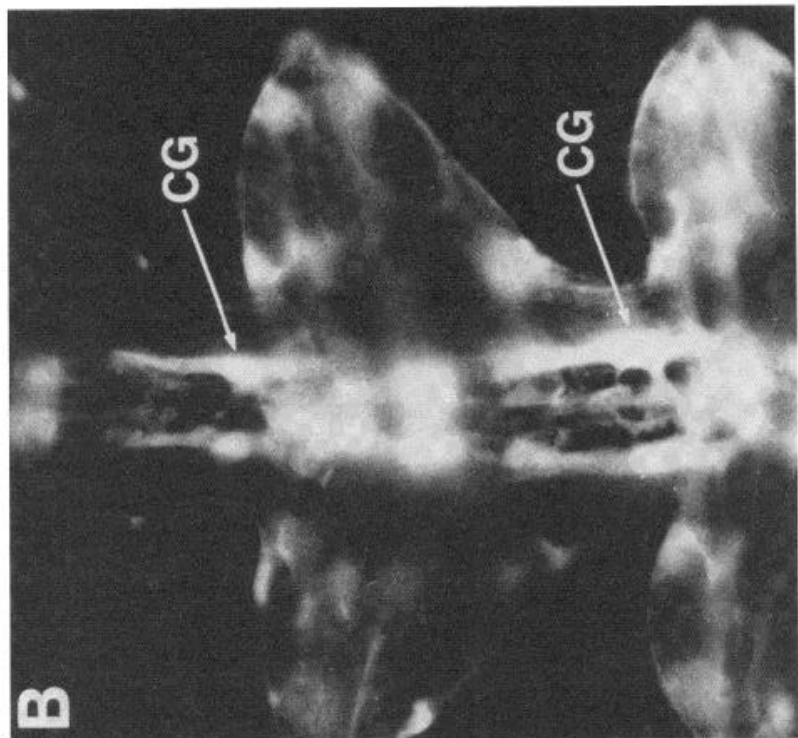

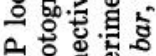

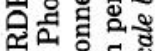

पn.

옹ㅎㅀ

50

踏

目要这

웡혀웛

월

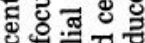

क्षे

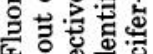

<

a.

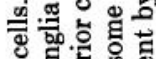

용ㅎㅀ

政
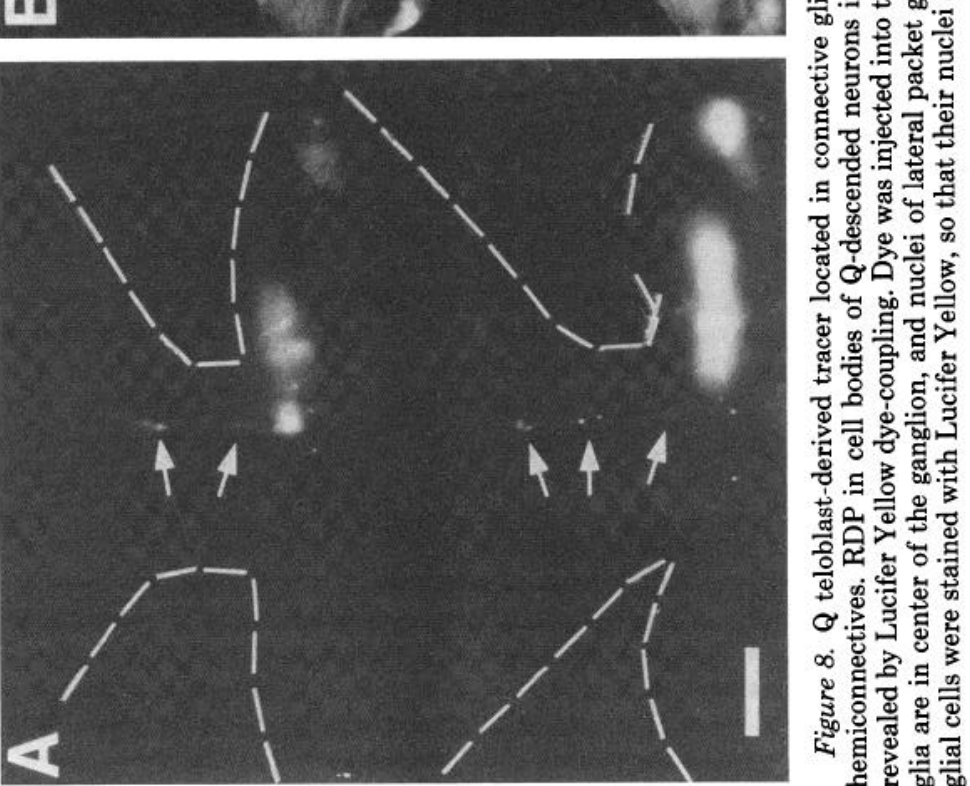
TABLE II

Types of ganglionic cells in kinship groups

Cell counts (No.) represent the average number or range over all specimens examined. These results are combined from observations on ganglia in a variety of body segments, even though some segmental differences in cell counts were apparent; these segmental differences have been ignored in this account. The question mark in the number column means data are missing; - means that available evidence indicates this cell type is not present but data are insufficient to be conclusive (the latter case is indicated by a 0 ); $a+$ after a number means that this is a minimum number and there are likely to be more such cells.

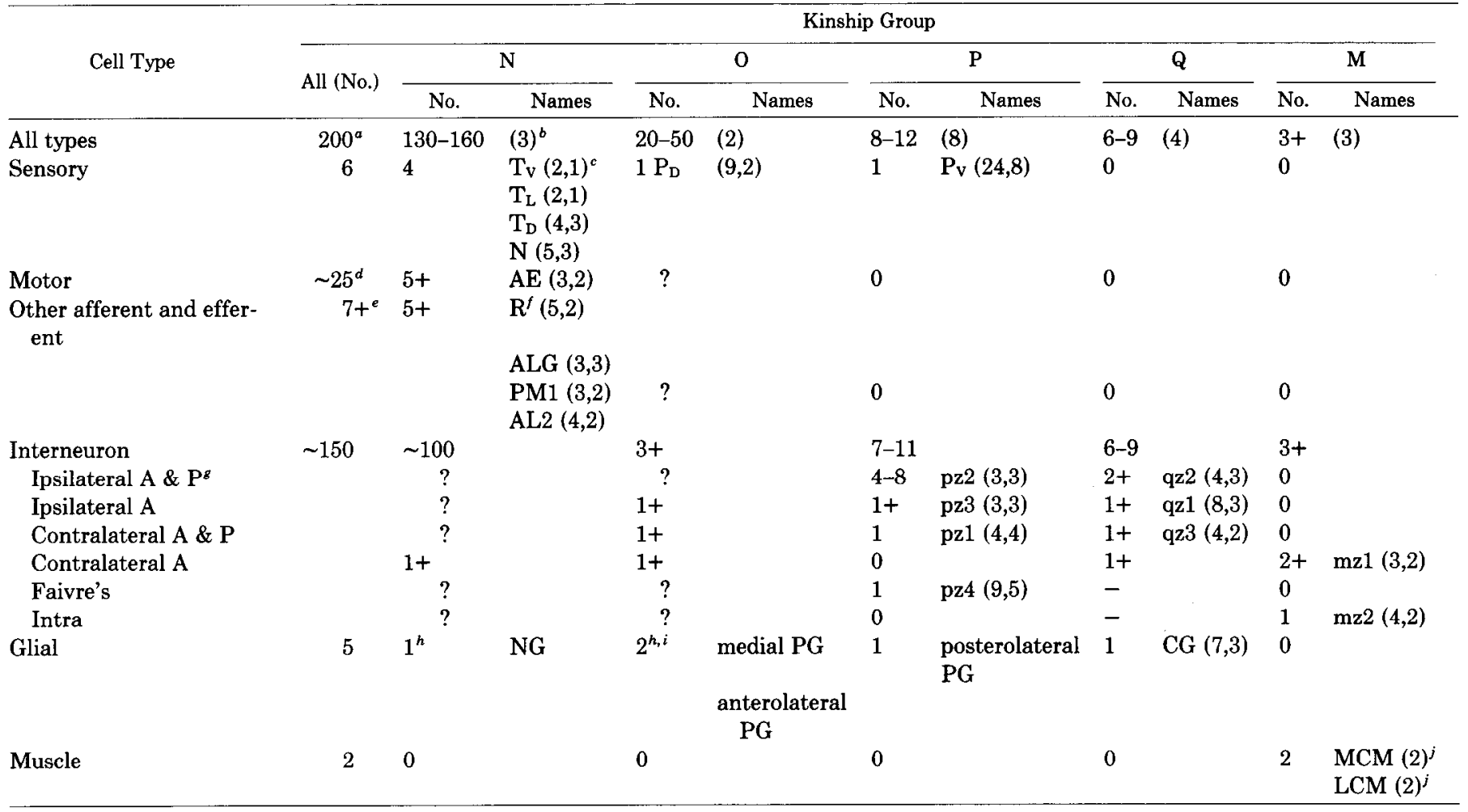

${ }^{a}$ Approximately 180 paired and 20 unpaired cells (Macagno, 1980).

${ }^{b}$ Number in parentheses, number of specimens examined.

${ }^{c}$ Number in parentheses, number of times cell containing tracer was identified followed by number of specimens examined.

${ }^{d}$ Estimate based on Hirudo medicinalis (Muller et al., 1981).

${ }^{e}$ Leydig and AL1 neurons were not examined.

${ }^{f}$ R, Retzius cell; NG, neuropil glia; PG, packet glia; CG, connective glia; MCM and LCM, medial and lateral connective muscle cells, respectively.

${ }^{g}$ Ipsilateral, Contralateral, and Faivre's designate axon projection into ipsilateral, contralateral, or unpaired medial connective nerve, respectively; A and A \& $\mathrm{P}$ designate axon projection into only anterior or into both anterior and posterior connective nerve, respectively; Intra designates restriction of axon projection to ganglion of cell body.

${ }^{h}$ Based on Helobdella traiserialis.

${ }^{i}$ Also confirmed by ablation studies in Helobdella (A. P. Kramer and S. S. Blair, unpublished observation).

${ }^{j}$ Identified visually in two Haementeria specimens (also true for Helobdella; Weisblat et al., 1984).

of the mature form of these neurons. If they are the mature form, this group of neurons could be thought of as a common morphological type in the $\mathrm{P}$ kinship group. Nevertheless, there are two other P-derived interneurons whose morphologies are qualitatively different. One of these, which we designate pz1, projects its axon through the ventral commissure to the contralateral side of the ganglion where it bifurcates and courses for many segments both anteriorly and posteriorly ("Contralateral A \& P" in Table II; Fig. 11). Neuron pz1 appears to be present in all midbody ganglia. The other qualitatively different interneuron, which we designate $\mathrm{pz} 4$, has the characteristics of an unpaired neuron. Its axon courses in Faivre's nerve, the median connective nerve tract that contains axons of unpaired neurons (Fig. 12); its pattern of neuropilar arborization is symmetrical about the midline (Fig. 12), and after the teloblast on either one side of the embryo or the other has been injected with RDP, a tracer-labeled pz4 neuron is found with random distribution in only about half of the segmental ganglia (Fig. $9 \mathrm{C}$ ).
This last observation suggests that there is only one pz4 cell body per ganglion, which arises sometimes from the left and sometimes from the right $P$ teloblast. The pz4 neuron appears to be present in all midbody ganglia and projects its axon anteriorly from its segment of origin to the subesophageal ganglion; those pz4 neurons located in the posterior sector of the nerve cord also extend a short axon to the next posterior ganglion (Fig. 12).

In accord with the metameric structure of the leech body, the $P$ kinship group forms segmentally repeating units, each unit being the progeny of a single primary p blast cell. However, contrary to expectation, the ganglionic progeny of one $p$ blast cell are distributed over two adjacent ganglia (D. A. Weisblat and M. Shankland, manuscript in preparation; see also Weisblat et al., 1980a; Zackson, 1982). The progeny distributed to the anteriormost ganglion are referred to as the anterior subset and those distributed to the more posterior ganglion are called the posterior subset. Consequently, the $\mathrm{P}$ kinship group in each 


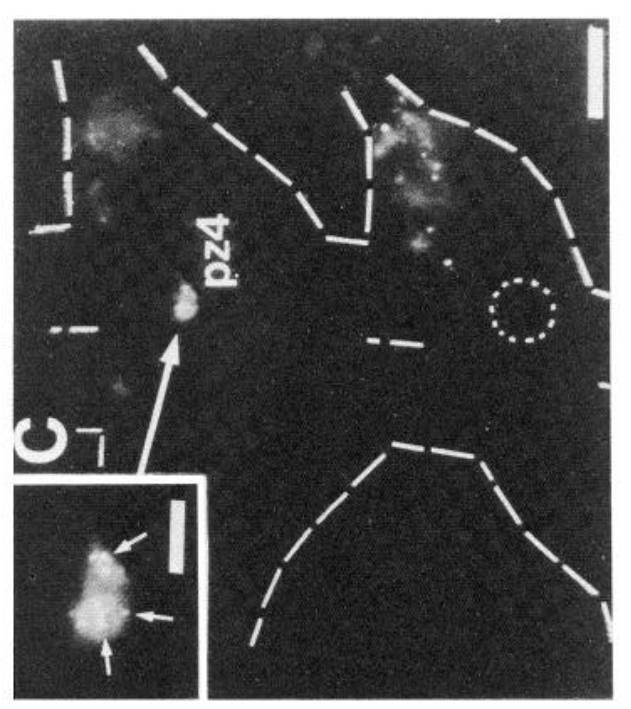

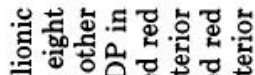

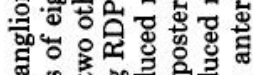

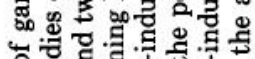

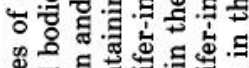

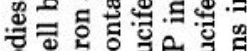
웡 क्ष .

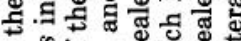

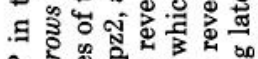

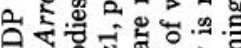
वิ 응 $\overline{0}$ 听. 贸 ํㅕㄴ.

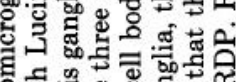

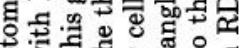

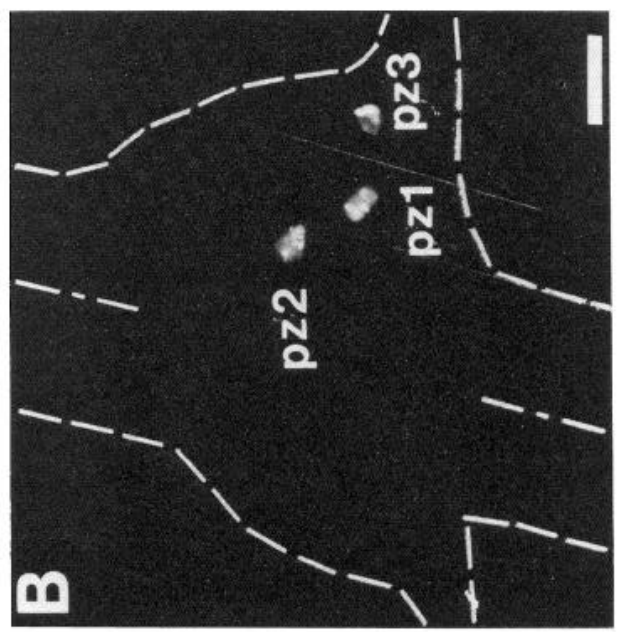

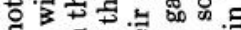

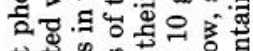

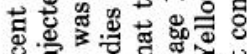
品 년

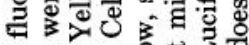

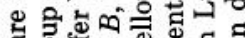
क ० 둥 돈

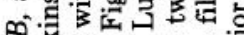

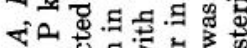
.

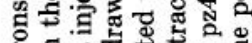

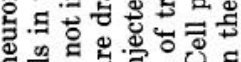
的

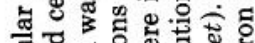

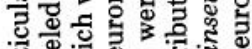

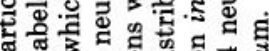

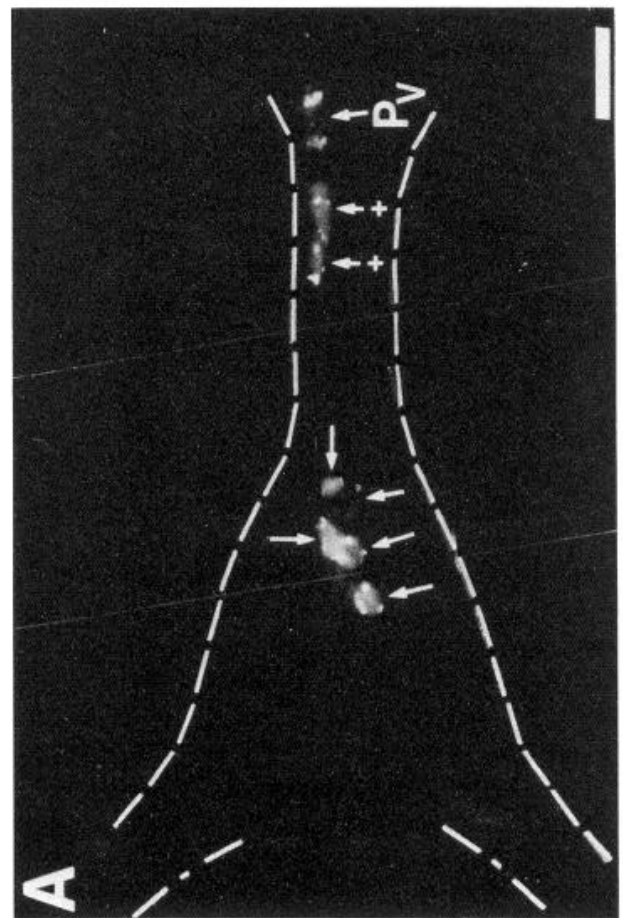

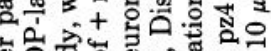

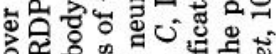

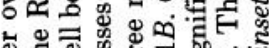

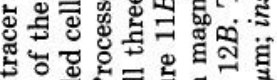

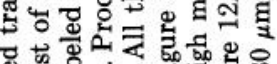
ఫ 눙

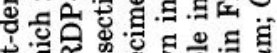

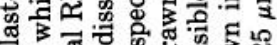
औ

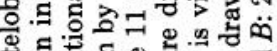
동 을

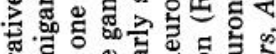
훙ㅎㅀ

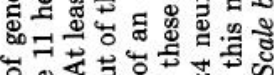

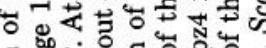
ธี

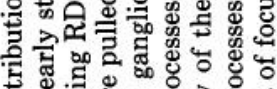

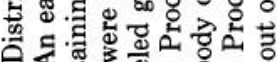

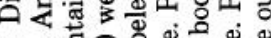

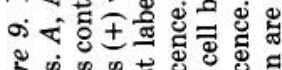

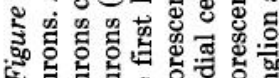

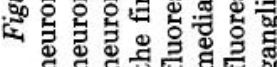



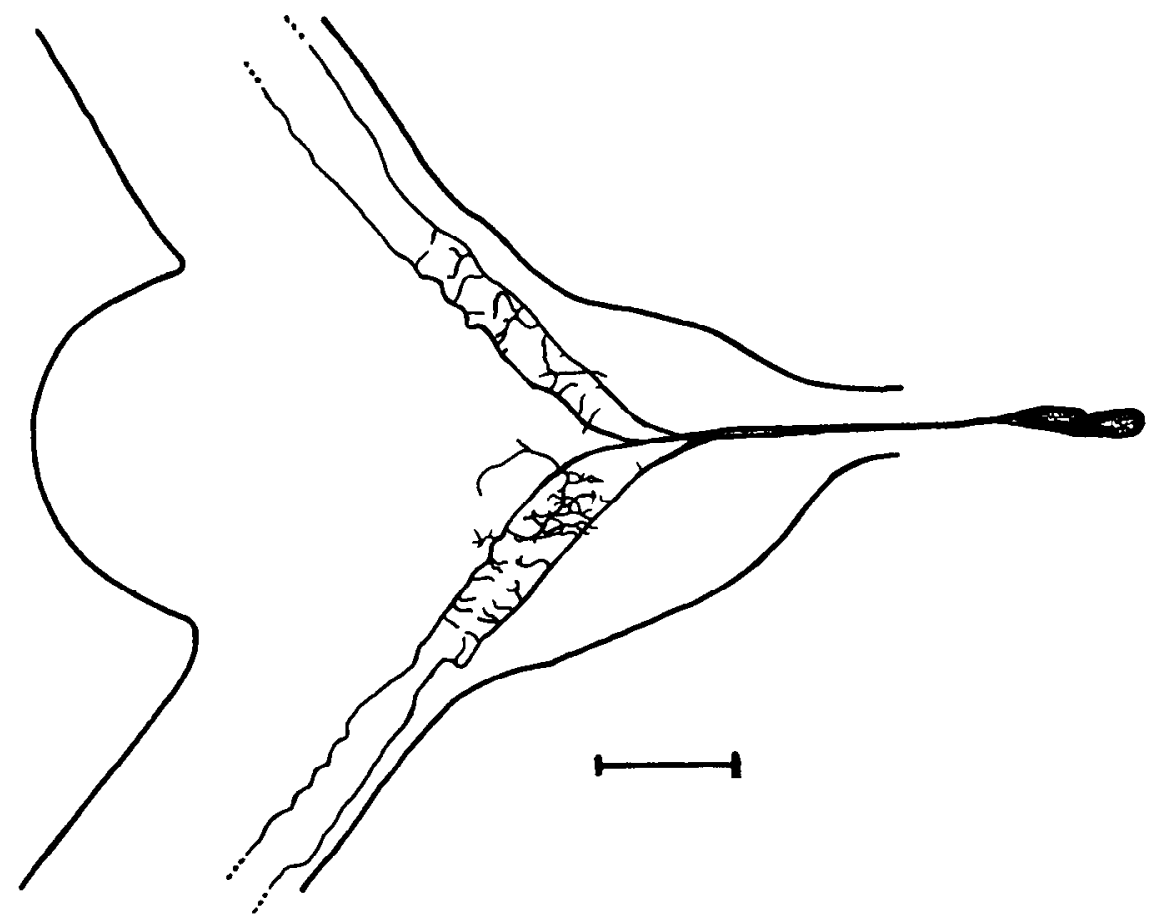

Figure 10. Morphology of two unidentified interneurons of the $\mathrm{P}$ kinship group. In this and other drawings of neurons, ganglion outlines are drawn as thin solid lines, and axons that continue but are not drawn are indicated by a dotted line. This drawing is of the two neurons indicated by a + in Figure $9 A$. Cell bodies were pulled out of the ganglion by the dissection. Both have similar neuropilar processes in the same confined region and project long ipsilateral anterior and posterior axons. Scale bar, $40 \mu \mathrm{m}$. half-ganglion is composed of an anterior subset from one $p$ blast cell and a posterior subset from another $\mathrm{p}$ blast cell. The anterior subset can be identified and characterized in the following way. If the $\mathrm{P}$ teloblast is injected with tracer after blast cell production is already underway, the resultant nerve cord will consist of unlabeled anterior and labeled posterior ganglia because the older blast cells contribute the more anterior ganglia (Weisblat et al., 1980a). The first labeled ganglion at the boundary between labeled and unlabeled nerve cord will contain tracer only in its anterior subset of P-derived neurons from the first labeled blast cell, since its posterior subset will be derived from the last unlabeled blast cell. We examined the first labeled ganglion in three such embryos and found in each case the same three labeled neurons (Fig. 9B). One of these is the pz1 neuron. Another, designated pz2, is among the interneurons that project long axons anteriorly and posteriorly in the ipsilateral connective (Fig. $11 A$ ). In stage 10 embryos, pz2 appears to be a bipolar neuron, but it later becomes monopolar. The third neuron, designated pz3, also is an ipsilaterally projecting interneuron, but it appears to project a long axon anteriorly and a short axon posteriorly (Fig. $11 B$ ). Thus, the anterior subset of neurons in the kinship group of the $P$ teloblast consistently contains the same three neurons, and by inference the remainder of the P kinship group is contained in the posterior subset. This further supports the inference that the lineage of neurons in the ganglion is highly determinate. The location of these and the other cells in the $\mathrm{P}$ kinship group is shown in Figure 1.

Neurons of the Q kinship group. All of the stage 6 to 9 neurons of the $Q$ kinship group are apparently interneurons. One of these is located laterally, ventral to the MA nerve tract, and the rest are located in the anterior medial packet, just anterior to the Retzius cell (Fig. 1). The interneuron located laterally is designated qz1 and is somewhat similar in morphology to the neurons of the $\mathrm{P}$ kinship group located in this region (Fig. $13 A$ ), in that it projects an axon ipsilaterally through many anterior ganglia but to only one or two posterior ganglia. However, its neuropilar arborization is more extensive than that of the $\mathrm{P}$ group interneurons at the same developmental stage. At least two of the Q-derived neurons in the anterior medial packet project axons ipsilaterally to anterior and pos- terior ganglia. One of these has been designated qz2. It has a large cell body compared to most other $Q$ kinship group neurons in early stage 11 embryos, and it is initially bipolar (Fig. 13R). Its neuropilar branches are also rather characteristic in that they project laterally from the axon. At least two other $Q$ kinship group neurons project axons contralaterally. The neuron we designate as qz3 projects through many segments both anteriorly and posteriorly, and has a relatively large cell body and short neuropilar processes at early stage 11 (Fig. 13B).

Neurons of the $M$ kinship group. At least three neurons arise from the mesoteloblast. Although we did not observe action potentials in these cells, possibly due to cell damage upon penetration with the microelectrode, their morphology is characteristic of that of a typical leech central neuron (Fig. 14). All of the cells of the $\mathrm{M}$ kinship group are interneurons of distinctly related morphology. They cluster in the posterior part of the anterior lateral packet near the dorsal aspect but lie under other cell bodies, so that they are difficult to penetrate with microelectrodes (Fig. 1). From each of these cells an axon projects across the midline to the contralateral side of the ganglion and then turns anteriorly. The axons of at least two of these cells project out of the ganglion into anterior ganglia. One of them is designated mz1 (Fig. 14A). The axon of another $\mathrm{M}$ group neuron, designated $\mathrm{mz2}$, apparently does not leave the ganglion, at least not by early to middle stage 11 (Fig. 14B). Lineage tracer experiments with Helobdella embryos confirm that there are only a small number, probably fewer than five, of ganglionic cells in the M kinship group (Weisblat et al., 1984).

We also determined that the medial and lateral connective muscle cell pairs (Kuwada and Kramer, 1983) are descended from the $\mathrm{M}$ teloblast in Haementeria, just as is the case in Helobdella (Weisblat et al., 1980a).

\section{Discussion}

The experiments reported here were undertaken to test the hypotheses that in the leech the line of descent of identified neural cells from their teloblast precursors is determinate and that neural cells related by teloblast lineage have related structures or functions. Regarding the first hypothesis, it was found that each identified neuron and glial cell studied does indeed 
(A)

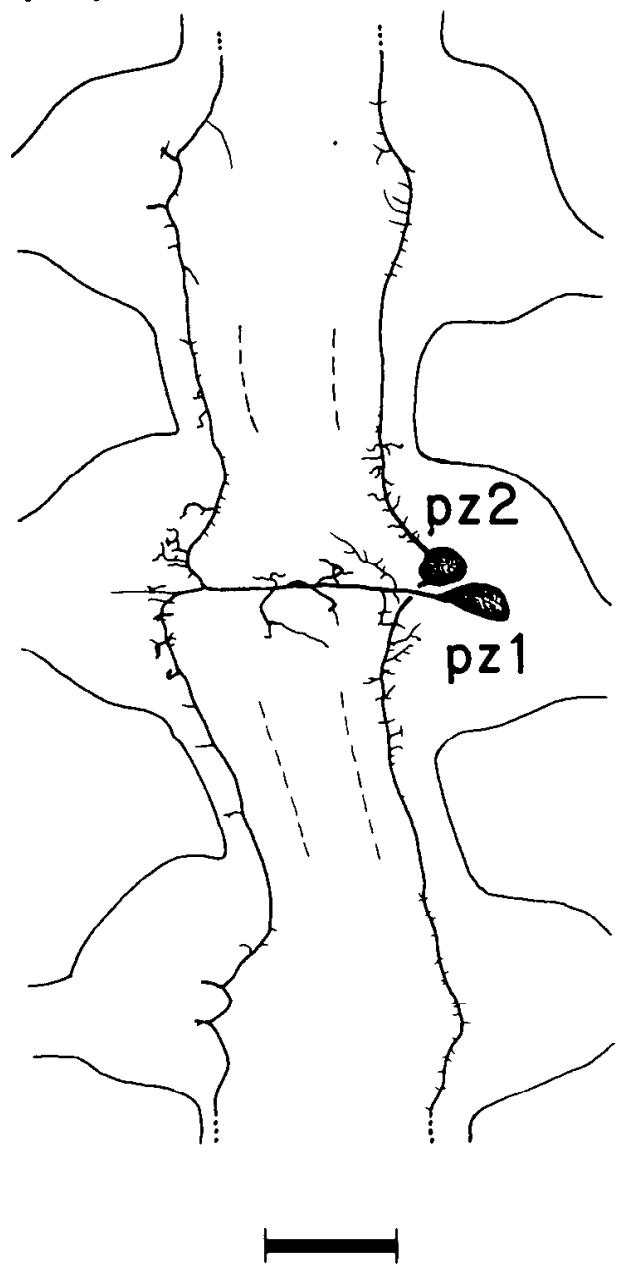

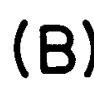

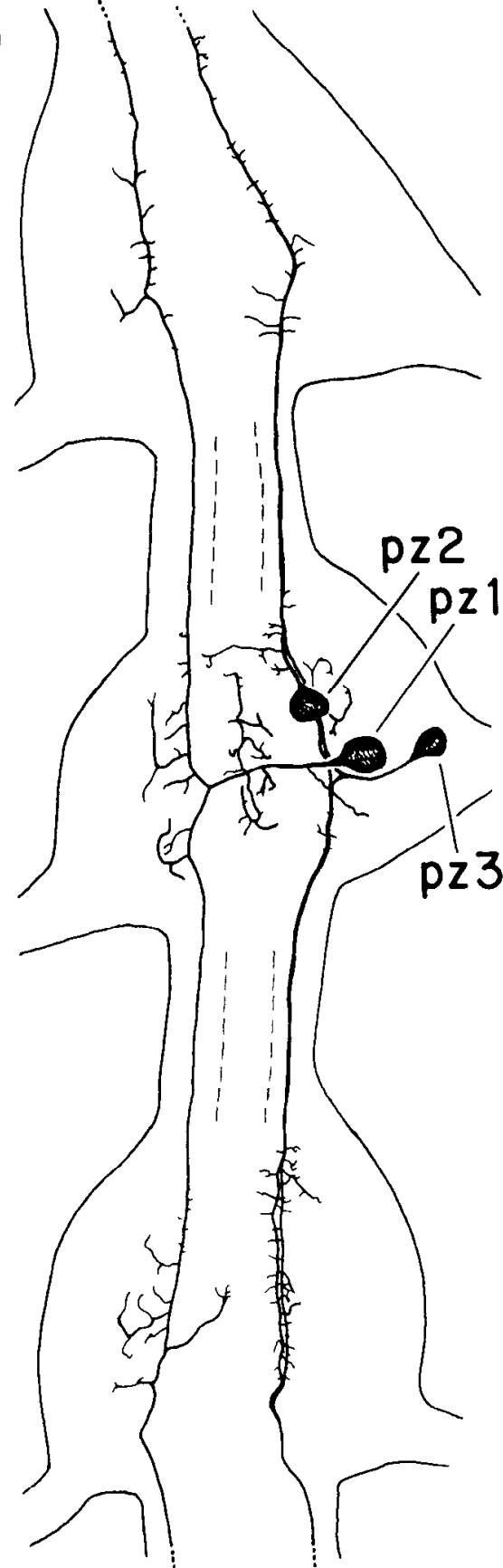

Figure 11. Morphology of the three interneurons of the $\mathrm{P}$ kinship group in the first labeled ganglion. In this and other drawings, the medial borders of the lateral connective nerves are indicated by dashed lines. A, Two of the three neurons, pz1 (with contralateral axon) and pz2 (with ipsilateral axon), in the same midbody ganglion in a middle stage 10 embryo. Cell pz:2 is still almost bipolar. $B$, All three neurons, pzl, pz2, and pz3, in a clitellar $(G 6)$ ganglion in an early stage 11 embryo. These are the same neurons photographed in Figure $9 B$. Cells pz2 and pz3 have similar ipsilateral processes. Cell pz2 is now monopolar. Scale bar, $40 \mu \mathrm{m}$.

arise regularly from a particular teloblast cell line (kinship group). This suggests that a neuron may owe its identity to one or more intrinsic factors inherited from its teloblast of origin and that, as the teloblasts are formed by cleavage of the egg, different factors are regularly segregated so that each teloblast is restricted in the set of neurons to which it can give rise. Regarding the second hypothesis, however, we found only a few properties that are segregated among the five neural kinship groups.

Determinacy of neural cell lineage. Previously described neural cells, including the six mechanosensory neurons and the giant glia of the ganglion and interganglionic connectives, were each found to belong to one kinship group exclusively (Tables
I and II). The lineage of neurons is so regular that we were able to characterize nine hitherto undescribed neurons, using kinship group as one of the criteria for identification. Together these results are strong evidence that each neural cell in the ganglion normally belongs to a particular kinship group and, conversely, that each teloblast kinship group is composed of a particular, invariant set of neural cells. Similar results have been reported for identified serotonin- and dopamine-containing neurons. All of the serotonin-containing neurons (located in the ganglion), including the Retzius neuron studied here, belong exclusively to the $\mathrm{N}$ kinship group, both in Haementeria and in Helobdella (D. K. Stuart, S. S. Blair and D. A. Weisblat, manuscript in preparation). However, each of the three iden- 
(A)

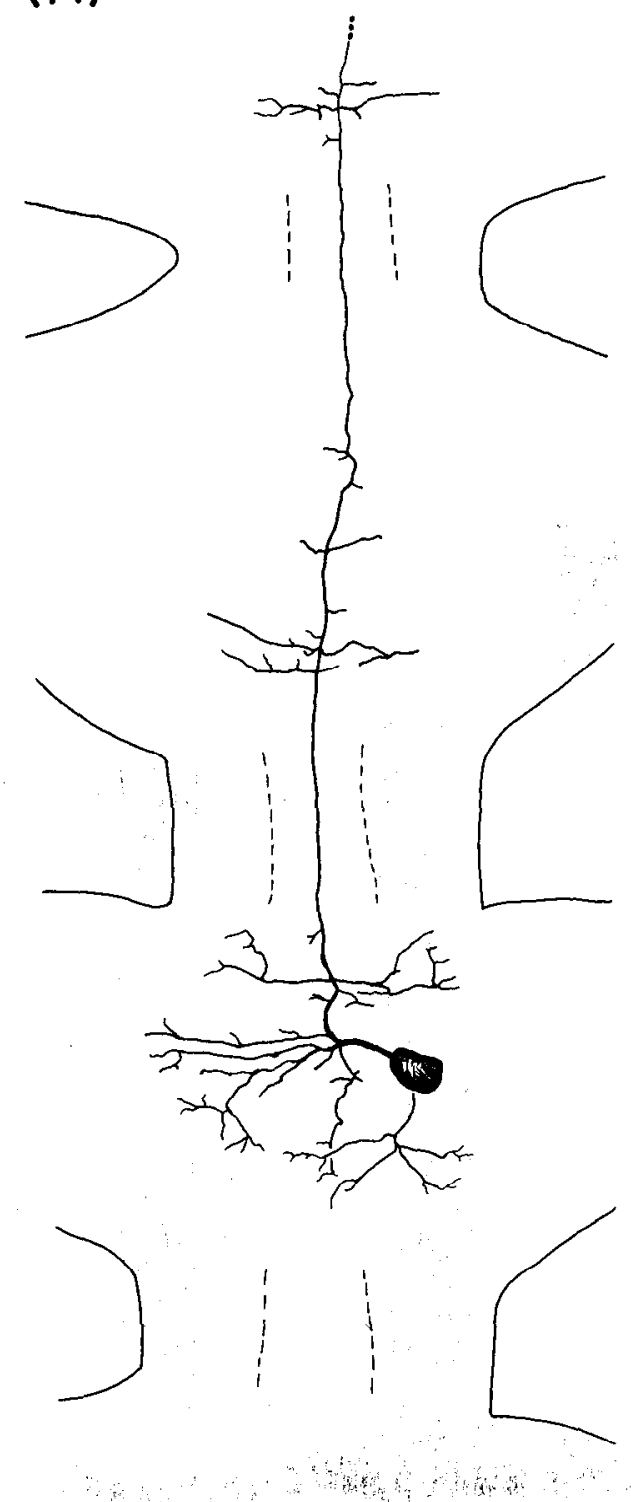

(B)

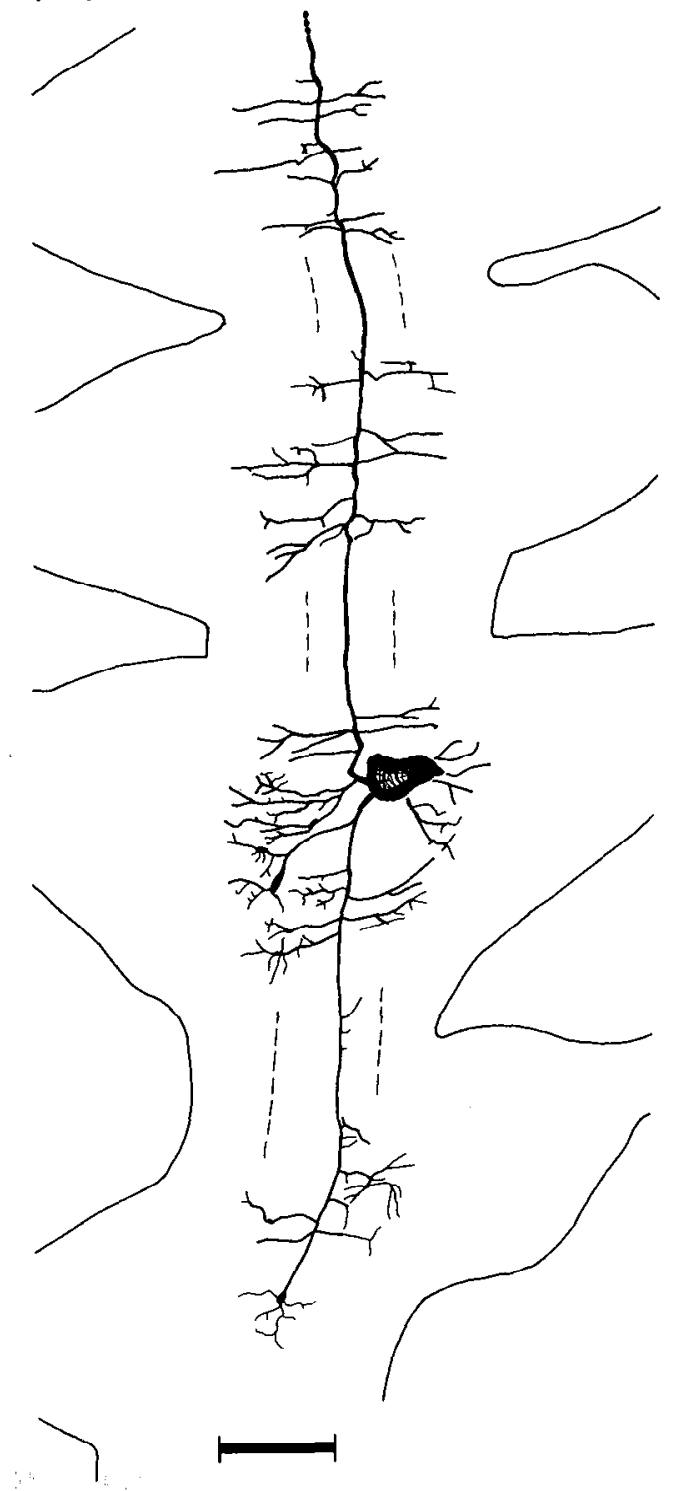

Figure 12. Morphology of interneuron pz4 of the $\mathrm{P}$ kinship group, which projects its axon in the midline Faivre's nerve. $A$, A pz4 neuron in midbody ganglion of an early stage 10 embryo. $B, \mathrm{~A}$ pz4 neuron in a posterior ganglion (G17) in a middle stage 10 embryo. This is the same neuron photographed in Figure 9 C. Scale bar, $30 \mu \mathrm{m}$.

tified peripheral dopamine-containing neurons belongs to a different kinship group in Helobdella. The MD neuron belongs to the $Q$ group, $\mathrm{LD}$ belongs to the $\mathrm{P}$ group, and $\mathrm{LD}_{2}$ belongs to the $\mathbf{O}$ group (D. K. Stuart, S. S. Blair and D. A. Weisblat, manuscript in preparation).

Since its kinship group membership, thus, is apparently a constant for any given neuron or glial cells, it would seem plausible that a neural cell's other identifying characteristics are fixed by its line of descent. Evidence for this would be that a particular cell cannot be generated by any teloblast other than its normal progenitor. In fact, ablation experiments generally support this prediction. For instance, ablation of an $\mathrm{N}$ teloblast early in development results in embryos with a deficit of neurons that normally descend from it, including the serotonin-containing neurons (Blair, 1983), the $\mathrm{T}$ and $\mathrm{N}$ mechanosensory neurons, and the ALG neuron (A. P. Kramer and S. $\mathrm{S}$. Blair, unpublished observations). Ablation of a $\mathbf{Q}$ teloblast results in a deficit of the MD dopamine-containing neurons that would normally descend from it (Blair, 1983). Also, ablation of the OP proteloblast (precursur of the sister $\mathrm{O} / \mathrm{P}$ telo- blasts) on one side results in a deficit of both $\mathrm{P}$ mechanosensory neurons and the packet glial cells (A. P. Kramer and S. S. Blair, unpublished observations) and of both $L D_{1}$ and $L D_{2}$ dopamine-containing neurons (Blair, 1983). Thus, the developmental potential of the $\mathrm{N}$ and $\mathrm{Q}$ teloblasts and the $\mathrm{OP}$ proteloblast appears to be determined at the time they are formed, so that they always give rise to these particular neural cells.

There is, however, an exception to this rule of determinacy. The $\mathrm{O} / \mathrm{P}$ teloblasts are of equal developmental potential; the fates of their progeny are decided later in development by interactions within the germinal band (Weisblat and Blair, 1984; M. Shankland and D. A. Weisblat, manuscript in preparation). Moreover, there is a hierarchical component to this fate-determining interaction such that either $\mathrm{O} / \mathrm{P}$ teloblast alone will generate progeny appropriate to the $\mathrm{P}$ kinship group, and a supernumerary $\mathrm{O} / \mathrm{P}$ bandlet appears constrained to make cells of the $\mathrm{O}$ kinship group (M. Shankland and D. A. Weisblat, manuscript in preparation). Thus, the ipsilateral $\mathrm{O} / \mathrm{P}$ teloblasts constitute a developmental equivalence group (Kimble et al., 

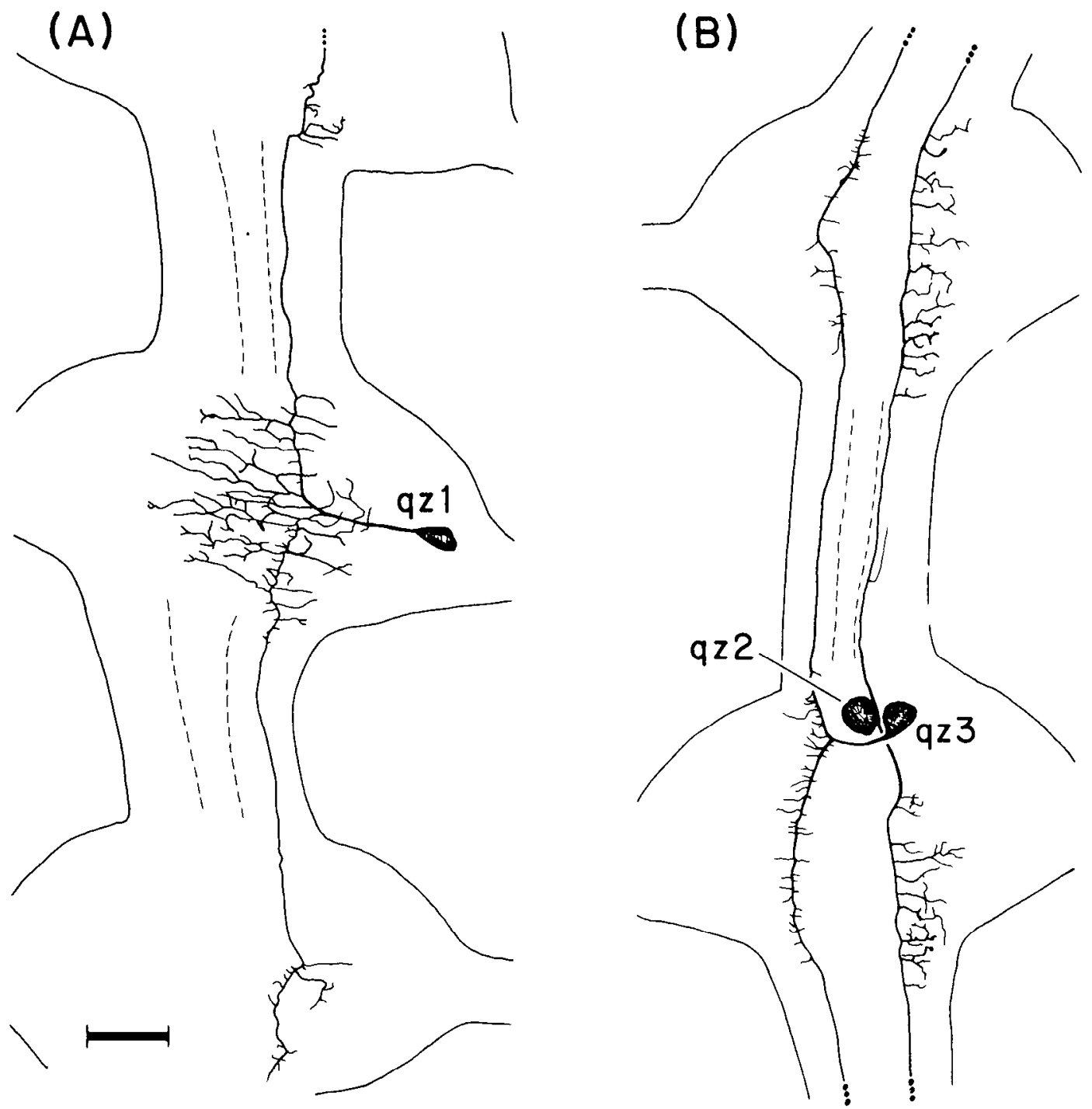

Figure 13. Morphology of some identified interneurons of the $\mathrm{Q}$ kinship group. $A$, The lateral neuron, qz1, in an early stage 11 embryo. $B$, The anterior medial packet neurons, qz2 and qz3, in a different ganglion of the same embryo. Cell qz2 has ipsilateral axons and qz3 has contralateral axons. Scale bar, $30 \mu \mathrm{m}$.

1979). (Note that both members of this equivalence group lie on the same side of the embryo. In contrast, the pz4 neurons (or their precursors) constitute a bilaterally situated equivalence group.) Although experimental evidence is not yet at hand, presumably these fate changes also occur for the identified $P_{V}$ and $P_{D}$ mechanosensory neurons shown here to belong to the $\mathrm{P}$ and $\mathrm{O}$ kinship groups, respectively. If so, these interactions of the $\mathrm{O} / \mathrm{P}$ teloblast lines may provide the explanation for the exceptional finding that in one ganglion of a specimen in which the P kinship group was labeled, there occurred also, apparently in addition to the normal labeled $P_{\mathrm{V}}$ neuron, an abnormally labeled $P_{D}$ neuron. The ganglion in which this anomaly occurred was also unusual in that it contained a larger number of labeled neurons than is usual for the $\mathrm{P}$ kinship group. Thus, perhaps this ganglion had, for some unknown reason, supernumerary $\mathrm{O} / \mathrm{P}$ progeny, including an extra $\mathrm{P}$ mechanosensory neuron which, on the basis of the results with supernumerary $\mathrm{O} / \mathrm{P}$ cells described above, we would predict should take on an $\mathrm{O}$ kinship group fate and become a $\mathrm{P}_{\mathrm{D}}$ neuron.

The indeterminacy of the $\mathrm{O} / \mathrm{P}$ teloblasts indicates that there is no segregation of developmental fate at the cleavage of the OP proteloblast. Thus, we are not surprised to see similarities between the cells of the $O$ and $P$ kinship groups. For example, each of these teloblasts gives rise to one of the two $P$ mechanosensory neurons, which differ only by having receptive fields in different skin territories, and, as shown elsewhere (D. K. Stuart, S. S. Blair and D. A. Weisblat, manuscript in preparation), each generates one of the two $\mathrm{O} / \mathrm{P}$-derived peripheral dompamine-containing neurons. Even their glial cell progeny are similar: each teloblast gives rise to one or two packet glial cells that differ only in the set of ganglion cell bodies they surround. An attractive possibility is that homologous lines of descent from the two $\mathrm{O} / \mathrm{P}$ teloblasts lead to $\mathrm{P}$ mechanosensory and lateral dopamine-containing neurons and to packet glial cells. Whether a $\mathrm{P}$ mechanosensory neuron innervates a dorsal or ventral field may thus depend on interactions with extrinsic factors during neurogenesis or axonogenesis rather than on intrinsic factors passed down from the teloblast of origin. Similar mechanisms may operate in the acquisition of particular identities by the otherwise similar packet glial cells and lateral dopamine-containing neurons. Although the $\mathrm{O}$ and $\mathrm{P}$ kinship groups may be thus composed in part of progeny from homologous cell lines, the observation that the $O$ kinship group comprises several times more neurons than does the $\mathrm{P}$ group indicates that the $O$ group has some cells that are clearly 

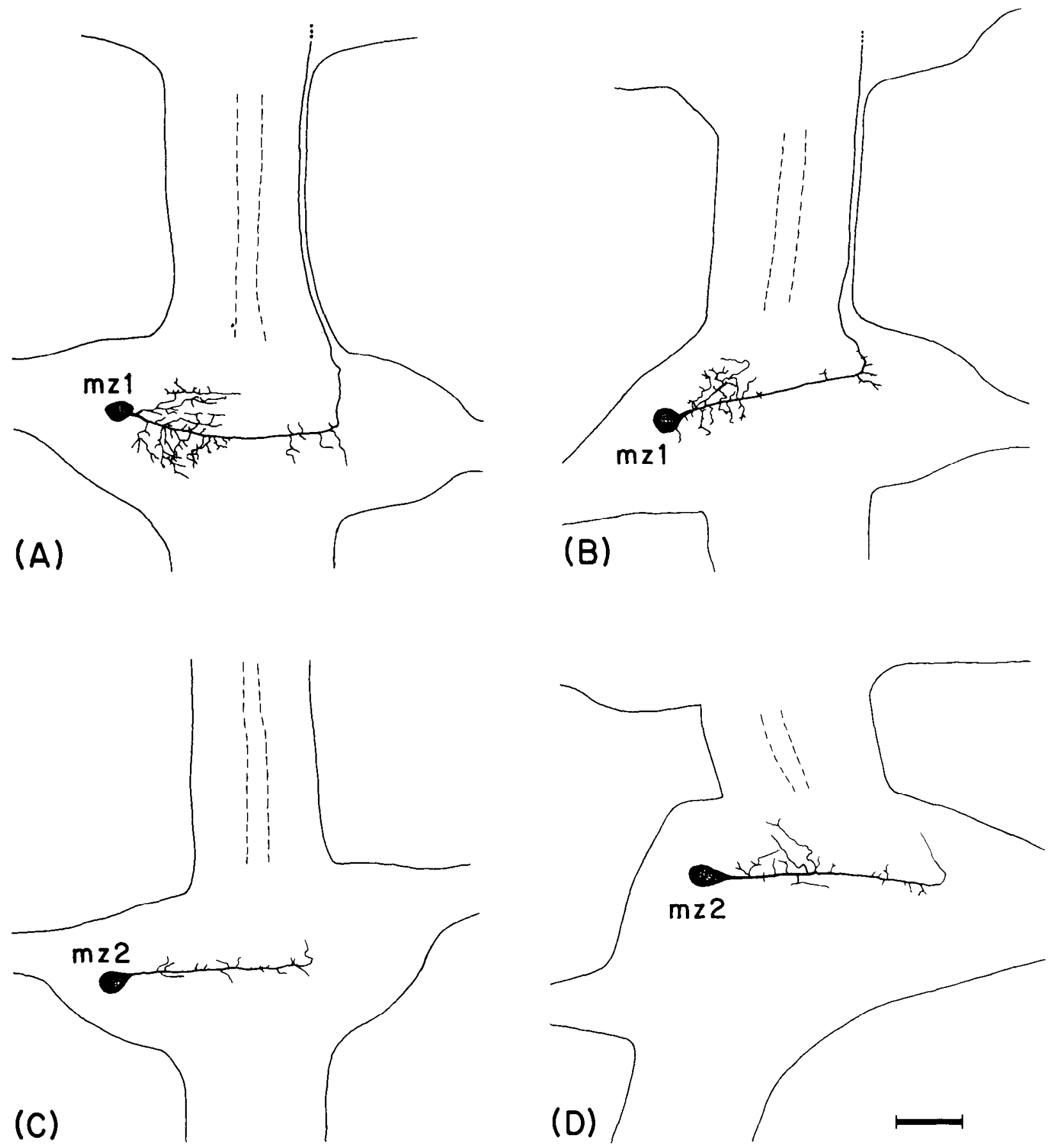

Figure 14. Morphology of some identified interneurons of the $\mathrm{M}$ kinship group. $A$ and $B$, Two examples of the same neuron, mz1, in the same stage 11(4/20) embryo. $C$ and $D$, Two examples of an apparently intraganglionic neuron, mz2. The neuron in $C$ is from the same embryo as in $A$ and $B$ and the neuron in $D$ is from an embryo 1 day older. Scale bar, $30 \mu \mathrm{m}$.

without homologues in the $\mathrm{P}$ group. In Caenorhabditis elegans many equivalence groups generate cells that are of apparently unrelated morphology and function (Sulston and White, 1980).

Relationship of lineage and neuronal structure and function. Even if the $\mathrm{O} / \mathrm{P}$ teloblasts are conceptually merged on the basis of their apparent equivalence, there remain four precursors from which segmental neurons arise determinately. Thus, we can ask, what components of the nervous system descend from each such precursor? Are the functional and structural classes of neural cells in the leech nerve cord thematically divided among the several precursor lines? Since the time of Whitman, models for development have been based on the assumptions that successive cleavages of an embryonic blastomere progressively restrict the developmental fates of the progeny and that this progressive developmental restriction would operate with a certain logic of design. By these models we would expect to see a separation of neural properties during genesis of the teloblasts. In fact, some such restrictions may occur upon formation of certain teloblasts from their precursor blastomeres. For instance, the cleavage of the NOPQ proteloblast into the $\mathrm{N}$ teloblast and an $\mathrm{OPQ}$ proteloblast has been shown to segregate serotonergic ( $\mathrm{N}$ teloblast line) from dopaminergic (O, P, and Q lines) potential (D. K. Stuart, S. S. Blair and D. A. Weisblat, manuscript in preparation). Also, the cleavage of 
the OPQ proteloblast into the $\mathrm{Q}$ teloblast and an OP proteloblast serves to complete the segregation of progenitors of glia that wrap cell bodies (the $\mathrm{O} / \mathrm{P}$ lines) from those that wrap cell processes (the $\mathrm{N}$ and $\mathrm{Q}$ lines).

On the whole, however, we found no obvious structural, functional, or topographical relationship among neural cells of a given kinship group, and several types of neural cells with closely related functions and structures were found to belong to different groups (Table II, Fig. 1). Not even neuronal and glial cell fates are segregated by formation of the teloblast precursors of the nervous system; neurons and glial cells of the nematodes are also closely related by lineage (Sulston and Horvitz, 1977; Sulston et al., 1983). Thus, it is possible that the restriction of developmental potential upon formation of the teloblasts is without teleological significance. Instead, as has been proposed elsewhere, its significance may be historical (Weisblat and Blair, 1982; Weisblat et al., 1984). According to this proposal, the pattern of neurogenesis observed in the leech is a vestige of the developmental pattern of a pre- or protoannelid that had a distributed nervous system of at least four paired nerve cords, each of which would have been derived from a different precursor (teloblast). As evolution proceeded, a more modern, centralized nervous system was achieved by having the blast cells of the laterally situated nerve cords migrate medially during late embryogenesis rather than by altering early embryogenesis so that all neurogenic potential would be transferred to a single medial $(\mathrm{N})$ teloblast. Thus, the ventral nerve cord of the modern leech still arises from multiple teloblasts. Since each distributed nerve cord in this presumptive ancestral annelid would probably subserve similar functions, differing mainly in the region of body wall subserved, each nerve cord would include diverse types of neural cells. Therefore, each of the multiple nerve cord cell lines of the ancestor might have included many of the same cell types, such as glia, mechanosensory neurons, or interneurons of various structural types. There would be no reason to expect the ancestral teloblast cell lines to have divided up the nervous system by major functional and structural classes. It is not our purpose to defend the credibility of this proposal; we mention it merely to point out the possibility that the progressive restrictions of developmental potential seen in determinate cell lineage patterns may be less related to an embryonic mechanism for efficiently or logically segregating developmental potential than to the evolutionary history of the system.

Mesodermal neurons. A final observation of interest in these experiments is support of the suggestion (Weisblat et al., 1984) that mesodermal ( $M$ teloblast-derived) ganglionic cells are neurons. In fact, they appear to be typical interneurons (Fig. 14). Similar observations have been made in the cell lineage of the nematode $C$. elegans (Sulston et al., 1983). These results contradict the generalizations of the germ layer theory, according to which the skin and nervous system are exclusively derived from the embryonic ectoderm. An alternative may be built upon the idea that the nervous system is an evolutionary derivative of epithelium, for which it obtained the basic forms of the highly specialized intercellular junctions which we now classify as chemical and electrical synapses. Adopting that view, it would not be surprising to observe neurons of mesodermal and endodermal provenance as well, since all of the germ layers have the capacity to generate epithelia. In this regard it is of interest to note that neurons of the supraesophageal ganglion of the leech have been shown to arise from the A, B, and C macromeres of the four-cell embryo (Weisblat et al., 1984), which, according to Whitman (1887), are endodermal precursors.

Comparison to other organisms. The conclusions reached in this study may indicate certain general principles of neurodevelopment among the lower invertebrates. Our results with the leech correspond, so far as is known, with those obtained in the nematode $C$. elegans, for which the complete cell lineage has been elucidated (Sulston and Horvitz, 1977; Deppe et al., 1978; Sulston and White, 1980; Sulston et al., 1983). For example, although the determinants for neuronal development per se are not segregated from those for other cell types during early development, each different neural lineage is largely stereotyped; developmental equivalence groups exist in which equivalent cells assume different fates on the basis of a hierarchical interaction; finally, cells of related structure and function do not necessarily arise from the same kinship group, and neurons within a kinship group are not obviously related in structure and function. Compared to the nematode, however, it seems that the leech exhibits more apparently random variability in the cellular composition of both non-neural tissues, such as the epidermis (Blair and Weisblat, 1984), and the segmental ganglia (Macagno, 1980). The comparison between leech and insect neurogenesis is also intriguing. These two groups are held to be closely related phyletically (Anderson, 1973; Sawyer, 1984), and yet their early development and neurogenesis proceed by markedly different paths. Whereas the leech develops from the egg by holoblastic cleavages and via segmental precursor cells (the primary blast cells) which generate both neural and non-neural tissues, insect embryos undergo several rounds of nuclear division prior to cellularization, and segmentedly iterated sets of neuroblasts have been described which give rise to exclusively neural progeny (Bate, 1976).

\section{References}

Anderson, D. T. (1973) Embryology and Phylogeny in Annelids and Arthropods, Pergamon Press, Oxford.

Bate, C. M. (1976) Embryogenesis of an insect nervous system. I. A map of the thoracic and abdominal neuroblasts in Locusta migratoria. J. Embryol. Exp. Morphol. 35: 107-123.

Blair, S. S. (1982) Interactions between mesoderm and ectoderm in segment formation in the embryo of a glossiphoniid leech. Dev. Biol 89: $389-396$.

Blair, S. S. (1983) Blastomere ablation and the developmental origin of identified monoamine-containing neurons in the leech. Dev. Biol. 95: 65-72.

Blair, S. S., and D. A. Weisblat (1982) Ectodermal interactions during neurogenesis in the glossiphoniid leech Helobdella triserialis. Dev. Biol. 91: 64-72.

Blair, S. S., and D. A. Weisblat (1984) Cell interactions in the devel oping epidermis of the leech Helobdella triserialis. Dev. Biol. 101 318-325.

Deppe, U., E. Schierenberg, T. Cole, C. Krieg, D. Schmitt, B. Yoder. and G. von Ehrenstein (1978) Cell lineages of the embryo of the nematode Caenorhabditis elegans. Proc. Natl. Acad. Sci. U. S. A. 75 376-380.

Kimble, J. J. Sulston, and J. White (1979). In "Cell Lineage, Stem Cells and Cell Determination," INSERM Symposium No. 10 (N. le Douarin, ed.), pp. 59-68. Elsevier, Amsterdam.

Kramer, A. P., and J. R. Goldman (1981) The nervous system of the glossiphoniid leech Haementeria ghilianii. I. Identification of neurons. J. Comp. Physiol. 144: 435-448.

Kramer, A. P., and J. Y. Kuwada (1983) Formation of the receptive fields of leech mechanosensory neurons during embryonic development. J. Neurosci. 3: 2474-2486.

Kuffler, S. W., and D. D. Potter (1964) Glia in the leech central nervous system: Physiological properties and neuron-glia relationship. J. Neurophysiol. 27: 290-320.

Kuwada, J. Y., and A. P. Kramer (1983) Embryonic development of the leech nervous system: Primary axon outgrowth of identified neurons. J. Neurosci. 3: 2098-2111.

Lent, C. M. (1977) The Retzius cells within the central nervous system of leeches. Prog. Neurobiol. 8: 81-117.

Macagno, E. R. (1980) The number and distribution of neurons in leech segmental ganglia. J. Comp. Neurol. 190: 283-302

Muller, K. J., J. G. Nicholls, and G. S. Stent (1981) Neurobiology of the 
Leech, Cold Spring Harbor Laboratory, Cold Spring Harbor, New York.

Nicholls, J. G., and D. A. Baylor (1968) Specific modalities and receptive fields of sensory neurons in CNS of the leech. J. Neurophysiol. 31: $740-756$.

Sawyer, R. T. (1984) Arthropodization in the Hirudinea: Evidence for a phylogenetic link with insects and other Uniramia? Zool. J. Linn. Soc. 80: 303-322.

Sawyer, R. T., F. LePont, D. K. Stuart, and A. P. Kramer (1981) Growth and reproduction of the giant glossiphoniid leech Haementeria ghilianii. Biol. Bull. 160: 322-331.

Stuart, A. E. (1970) Physiological and morphological properties of motoneurones in the central nervous system of the leech. J. Physiol. (Lond.) 209: 627-646.

Sulston, J. E., and H. R. Horvitz (1977) Post-embryonic cell lineages of the nematode Caenorhabditis elegans. Dev. Biol. 56: 110-156.

Sulston, J. E., and J. G. White (1980) Regulation and cell autonomy during postembryonic development of Caenorhabditis elegans. Dev. Biol. 78: 577-597.

Sulston, J. E., F. Schierenberg, J. G. White, and J. N. Thomson (1983) The embryonic cell lineage of the nematode Caenorhabditis elegans. Dev. Biol. 100: 64-119.

Weisblat, D. A., and S. S. Blair (1982) Cell lineage in leech neurogenesis during normal development and after the ablation of identified blastomeres. NRP Bull. 20: 783-793.

Weisblat, D. A., and S. S. Blair (1984) Developmental indeterminacy in embryos of the leech Helobdella triserialis. Dev. Biol. 101: 326335 .

Weisblat, D. A., R. T. Sawyer, and G. S. Stent (1978) Cell lineage analysis by intracellular injection of a tracer enzyme. Science 202: $1295-1298$

Weisblat, D. A., G. Harper, G. S. Stent, and R. T. Sawyer (1980a) Embryonic cell lineages in the nervous system of the glossiphoniid leech Helobdella triserialis. Dev. Biol. 76: 58-78.

Weisblat, D. A., S. L. Zackson, S. S. Blair, and J. D. Young (1980b) Cell lineage analysis by intracellular injection of fluorescent tracers. Science 209: 1538-1541.

Weisblat, D. A., S. Kim, and G. S. Stent (1984) Embryonic origin of cells in the leech Helobdella triserialis. Dev. Biol. 104: 65-85.

Whitman, C. O. (1878) The embryology of Clepsine. Q. J. Micros. Sci. (N.S.) 18: 215-315.

Whitman, C. O. (1887) A contribution to the history of germlayers in Clepsine. J. Morphol. 1: 105-182.

Whitman, C. O. (1892) The metamerism of Clepsine. Festschrift zum 70. Geburtstage R. Leuckarts, Engelmann, Leipzig, pp. 385-395.

Zackson, S. L. (1982) Cell clones and segmentation in leech development. Cell 31: 761-770. 